CATALLAXY

Volume 2 Issue 2 December 2017

e-ISSN 2544-090X

¿ www.catallaxy.pl

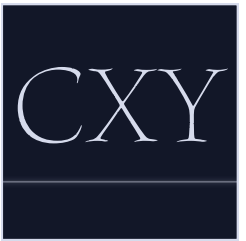

Oryginalny artykut naukowy

otrzymano: 01.11.2017 / zaakceptowano: 01.12.2017 / opublikowano online: 31.12.2017

(9)(1)

Zygadlewicz, M. (2017). Prywatyzacja branży telekomunikacyjnej w Polsce a sytuacja finansowa Grupy Orange. Catallaxy, 2(2): 105-129. doi:10.24136/cxy.212.4.

\title{
Prywatyzacja branży telekomunikacyjnej w Polsce a sytuacja finansowa Grupy Orange
}

\author{
MACIEJ ZYGADLEWICZ \\ Uniwersytet Mikotaja Kopernika w Toruniu, Wydział Nauk Ekonomicznych i Zarządzania, ul. Gagarina 13a, 87-100 \\ Torun, Polska \\ \mzygadlewicz@gmail.com \\ iD orcid.org/0000-0003-4927-5462
}

\begin{abstract}
Abstrakt
Motywacja: Telekomunikacja Polska SA (dalej TP SA) przez wiele lat miała pozycję monopolisty w branży telekomunikacyjnej w Polsce. Proces prywatyzacji spółki rozpoczął się w 1998 roku, towarzyszyły mu zmiany w branży telekomunikacyjnej, w kierunku jej większej liberalizacji. Rozpoczęcie działalności przez nowych operatorów zwiększyło poziom konkurencji. Usługi były coraz tańsze dla konsumentów, rozpoczęto oferować usługi wiązane, a nowe technologie telekomunikacyjne rozwijały się bardzo szybko. Przekształcenia, jakie dokonywały się w branży telekomunikacyjnej, w znacznym stopniu wpływały na zmiany sytuacji finansowej Grupy Kapitałowej Orange Polska (dalej Grupa Orange). W literaturze przedmiotu brakuje interpretacji zależności między procesem prywatyzacji dokonującym się w branży telekomunikacyjnej a sytuacją finansową jej było monopolisty. Chęć ukazania tej zależności jest głównym motywem wyboru tematu niniejszego artykułu.

Cel: Celem niniejszego artykułu jest wykazanie zależności między prywatyzacją TP SA a sytuacją finansową Grupy Orange. Badanie zostało przeprowadzone za pomocą analizy finansowej i techniczno-ekonomicznej. Materiał empiryczny stanowią raporty i sprawozdania Grupy Orange.

Wyniki: Analiza wyników finansowych Grupy Orange w analizowanym okresie wykazała, że prywatyzacja TP SA wywarła negatywny wpływ na sytuacje finansową Grupy Orange.
\end{abstract}

Stowa kluczowe: prywatyzacja TP SA; liberalizacja branży telekomunikacyjnej; Grupa Kapitatowa Orange Polska; analiza finansowa; analiza techniczno-ekonomiczna

JEL: DOO; GOO; B52

1. Wprowadzenie

Celem niniejszego artykułu jest wykazanie zależności między prywatyzacją Telekomunikacji Polskiej SA (dalej TP SA) a sytuacją finansową Grupy Kapitałowej Orange Polska (dalej Grupa Orange).

Zakres czasowy artykułu obejmuje lata 2011-2016. W 2011 roku TP SA funkcjono- wała po raz pierwszy, jako $w$ pełni prywatne przedsiębiorstwo, po tym jak w 2010 roku zostały sprzedane na Giełdzie Papierów Wartościowych (GPW) ostatnie 4,15\% akcji TP SA należących do Skarbu Państwa. W przypadku opisu procesu prywatyzacji, zakres czasowy artykułu został poszerzony o lata 1998-2010.

W Sekcji 1. scharakteryzowany krótko został proces prywatyzacji $\mathrm{w}$ branży teleko- 
munikacyjnej w Polsce w latach 1998-2010. Została przedstawiona specyfika usług telekomunikacyjnych, została również zaprezentowana pozycja monopolistyczna TP SA $\mathrm{w}$ branży telekomunikacyjnej w Polsce, a następnie został ukazany proces liberalizacji tego rynku. W Sekcji 2. dokonany został przegląd literatury przedmiotu. W Sekcji 3. zawarty został opis wykorzystanych metod. W Sekcji 4. zostały ukazane wyniki finansowe Grupy Orange w latach 2011-2016 na tle procesu prywatyzacji. W celu zaprezentowania zmian, jakie dokonywały się w sytuacji finansowej byłego monopolisty branży telekomunikacyjnej w Polsce, została przeprowadzona analiza finansowa oraz analiza techniczno-ekonomiczna Grupy Orange. W Sekcji 5. zawarte zostało podsumowanie przeprowadzonej analizy.

\subsection{Charakterystyka usług telekomunikacyjnych}

Etymologia słowa telekomunikacja wskazuje na jego znaczenie. Wyraz ten pochodzi od dwóch wyrażeń: greckiego tele (odległy, daleko) i comunicare (dzielenie się z kimś). Telekomunikacja jest $\mathrm{w}$ takim razie metodą za pomocą, której osoby kontaktują się pokonując przeszkodę, którą stanowi m.in. odległość.

Telekomunikację można podzielić stosując różne klasyfikacje. W przypadku Grupy Orange najważniejszy jest podział usług w oparciu o sieć, ponieważ jest on wykorzystywany w raportach rocznych Grupy Orange. Wyróżnia się w nim usługi (Babis i Czaplewski, 2011, s. 195):

1. stacjonarne - są to usługi oparte o sieci stacjonarne, które zawierają przede wszystkim usługi:

- telefonii głosowej;

- dodane do telefonii głosowej;

- informacyjne dotyczące spisu abonentów;

- dzierżawy łączy;

- transmisji danych;

- dodane do transmisji danych;

- w zakresie zarządzania siecią;

- technicznego utrzymania sieci;

2. mobilne - są to usługi oferowane na bazie sieci radiokomunikacyjnych takie, jak:
- usługi wąskopasmowe pozwalające na przesyłanie głosu, danych i faksów;

- szerokopasmowe usługi transmisji danych;

- wiadomości SMS;

- usługi dodane;

- roaming międzynarodowy;

- usługi błyskawicznego odbierania poczty elektronicznej;

- wideokonferencji;

- aplikacji czasu rzeczywistego;

- połączenia z modemami stacjonarnymi;

- możliwości ciągłego korzystania z poczty elektronicznej;

- dostępu do Internetu;

- stosowania monitoringu;

- dokonywania usług transakcyjnych, w tym również bankowych.

Powyższy podział umożliwia szybkie przyporządkowanie poszczególnych usług do jednej z tych dwóch grup. Pozwala, w dalszej kolejności, określić przedsiębiorcom telekomunikacyjnym, co jest największym składnikiem ich przychodów.

\subsection{Monopol Telekomunikacji Polskiej SA na rynku usług telekomunikacyjnych w latach 1998-2000}

W 1991 roku powstała spółka akcyjna Skarbu Państwa o nazwie Telekomunikacja Polska. Ustawa o łączności (1990), stanowiła, że prowadzenie działalności telekomunikacyjnej na rynku lokalnym było zarezerwowane dla tej spółki oraz innych podmiotów, które otrzymały zezwolenie. W ten sposób formalnie zakończono monopol państwowy w branży telekomunikacyjnej. Jednak, w segmencie połączeń międzynarodowych, jedynym przedsiębiorstwem telekomunikacyjnym, któremu umożliwiono świadczenie usług była TP SA. Wprowadzono również zakazy „na używanie urządzeń, linii i sieci telekomunikacyjnych bezpośrednio połączonych drogą kablową, radiową lub w układzie międzynarodowych systemów satelitarnych $z$ liniami, urządzeniami lub sieciami znajdującymi się poza granicami Rzeczypospolitej Polskiej - podmiotowi zagranicznemu lub spółce z udziałem podmiotów zagranicznych", a także „na używanie międzymiastowych linii 
i sieci telekomunikacyjnych oraz na świadczenie międzymiastowych usług telekomunikacyjnych - podmiotowi zagranicznemu lub spółce $z$ udziałem podmiotów zagranicznych, jeżeli udział podmiotów zagranicznych w kapitale zakładowym lub akcyjnym przekracza 49\%" (Ustawa o łączności, 1990). Regulacje te, $w$ łącznym zestawieniu $z$ bardzo dużymi kosztami rozpoczęcia funkcjonowania na rynku telekomunikacyjny, będącymi efektem konieczności pozyskania licznych licencji i zezwoleń oraz stworzenia własnej sieci dostępowej, były ogromną barierą $\mathrm{w}$ procesie liberalizacji branży telekomunikacyjnej. Występowała sytuacja, w której istniał jedyny, faktyczny i potencjalny dostawca produktu lub usługi wytwarzanej w określonej gałęzi (Begg i in., 2007, s. 422) było TP SA.

W 1992 roku rozpoczą funkcjonowanie w Polsce rynek telefonii mobilnej z pierwszym operatorem, którym była Polska Telefonia Komórkowa Centertel Sp. z o.o. (dalej PTK Centertel), będąca w $51 \%$ własnością TP SA. Przedsiębiorstwo to miało również, od 1996 roku, dominującą pozycję $\mathrm{w}$ warunkach konkurencji monopolistycznej na rynku dostępu do Internetu. Posiadało zatem największe udziały na każdym rynku usług telekomunikacyjnych w Polsce.

Istotną przyczyną rozpoczęcia procesów realnej liberalizacji branży telekomunikacyjnej, było dążenie Polski do wstąpienie do Unii Europejskiej (UE). Wobec tego trzeba było podejmować starania, aby polskie prawo odpowiadało standardom europejskim, a zgodnie z Dyrektywą 96/19/WE (1996), państwom członkowskim UE zalecono pełną liberalizację branży telefonicznej. Najważniejszym jej punktem było umożliwienie korzystania z publicznych sieci telekomunikacyjnych operatorom alternatywnym tak, aby mieli możliwość oferowania usług $w$ powszechnej sieci telefonicznej (Budziewicz-Guźlecka, 2011, s. 108).

UE zalecała także, aby zainicjować proces prywatyzacji głównych sektorów gospodarki narodowej, w tym m.in. telekomunikacji. W 1997 roku Ministerstwo Skarbu Państwa opracowało koncepcję prywatyzacji TP SA, która planowała jej trzy etapy. Pierwszym etapem, który miał miejsce w 1998 roku, było wprowadzenie TP SA na GPW w Warszawie oraz na GDR (Global Depositary Receipts) $w$ Londynie oraz sprzedaż w ofercie publicznej 15\% akcji spółki. W 1999 roku zlikwidowano przepis o obowiązkowym posiadaniu, co najmniej 51\% akcji TP SA przez Skarb Państwa. W 2000 roku natomiast przystąpiono do drugiego etapu prywatyzacji, wyprzedając 35\% akcji konsorcjum France Telecom i Kulczyk Holding, które dzięki temu uzyskało status strategicznego inwestora TP SA.

\subsection{Liberalizacja rynku ustug telekomunikacyjnych w Polsce w latach 2001-2010}

1 stycznia 2001 roku zaczęła obowiązywać ustawa Prawo telekomunikacyjne (2000), uchwalona 21 lipca 2000 roku. Stanowiła ona znaczący postęp $\mathrm{w}$ procesie liberalizacji branży telekomunikacyjnej w Polsce.

Wszystkie działania miały na celu to, aby polskie prawo telekomunikacyjne coraz bardziej odpowiadało wymaganiom unijnymi. Kluczową kwestią, która wpłynęła na osłabienie pozycji TP SA jako monopolisty polskiej branży telekomunikacyjnej, było wprowadzenie przepisu, aby podmioty o znaczącej pozycji rynkowej umożliwiły używanie swoich łączy innym przedsiębiorstwom telekomunikacyjnym. Co więcej, cena dzierżawy była uzależniona tylko od rzeczywistego kosztu usługi dzierżawy, a dla ujednolicenia i klarowności umów wprowadzono wymóg, aby operatorzy przygotowali oferty wyznaczające zasady realizacji umowy dzierżawy (Kaczmarczyk, 2015 , s. 80 ). To postanowienie było najistotniejsze $\mathrm{w}$ procesie liberalizacji branży telekomunikacyjnej w Polsce. Wszystkie, następne decyzje już tylko go pogłębiały.

W 2001 roku dokonano trzeciego etapu $\mathrm{w}$ procesie prywatyzacji TP SA. Konsorcjum France Telecom i Kulczyk Holding zakupiło 12,5\% kolejnych akcji spółki. Francuski operator France Telecom w tym konsorcjum był przedsiębiorstwem o większych prawach i miał możliwość uzyskania następnych udziałów.

1 stycznia 2002 roku doszło do całkowitego uwolnienie segmentu połączeń międzystrefo- 
wych, a w 2003 roku połączeń międzynarodowych. Na rynku telefonii stacjonarnej zaczęli funkcjonować tacy operatorzy, jak: Netia SA, Telefonia Dialog Sp. z o.o., czy Tele2 Polska Sp. z o.o. Mimo to, wciąż bezsprzeczną, ponad $85 \%$ przewagę udziału w przychodach rynku, miała TP SA.

Wraz $z$ przystąpieniem Polski do UE 1 maja 2004 roku, należało stworzyć nowe ustawy, które spełniałby wymogi unijne. Przedstawione one zostały w tzw. nowym zestawie dyrektyw z 2002 roku, które wszyscy członkowie UE byli zobligowani wprowadzić do lipca 2003 roku. W Polsce ustanowiono je z opóźnieniem, uchwalając 16 lipca 2004 roku nowe Prawo telekomunikacyjne (2004), które zaczęło obowiązywać 3 września 2004 roku.

W 2004 roku wykorzystano jedną z klauzul umieszczonych $w$ umowie między France Telecom a Kulczyk Holding i zawarto porozumienie o przeniesieniu $13,57 \%$ akcji TP SA, które były w posiadaniu Kulczyk Holding, na rzecz France Telecom. W 2005 roku w branży telekomunikacyjnej pojawiła się marka Orange, pod którą zaczęła funkcjonować PTK Centertel. W 2006 roku, Urząd Komunikacji Elektronicznej (UKE), zastąpił Urząd Regulacji Telekomunikacji i Poczty (URTiP) i uzyskał jednocześnie więcej uprawnień.

W sierpniu 2010 roku Ministerstwo Skarbu Państwa sprzedało ostatnie 4,15\% akcji TP SA, doprowadzając całkowicie do końca proces prywatyzacji spółki. Proces liberalizacji branży telekomunikacyjnej (w szczególności rynku telefonii stacjonarnej) cały czas postępował, jednak zwiększono udziały w poszczególnych rynkach operatorów alternatywnych kosztem TP SA, która z roku na rok traciła pozycję monopolisty (UKE, 2011, s. 61). Dla konsumentów najważniejszy był fakt, że ceny usług telekomunikacyjnych $z$ roku na rok malały.

\section{Przegląd literatury}

W literaturze przedmiotu brak opracowań dotyczących opisów zależności między zakon- czonym procesem prywatyzacji TP SA a wynikami finansowymi Grupy Orange.

M. Raczyński (2006), komentuje procesu prywatyzacji TP SA, twierdząc, że władze ustawodawcze i wykonawcze świadomie stworzyły instytucje regulujące sektor telekomunikacyjny, pozbawione wystarczająco silnych uprawnień, tak aby nie były one w stanie przeciwstawić się grupom nacisku.

A. Budziewicz-Guźlecka (2011), ukazuje przebieg procesu prywatyzacji TP SA w świetle dostosowywania polskiego prawa telekomunikacyjnego do wymogów unijnych.

Skonsolidowanie raporty roczne Orange Polska (2012a-2017a), wskazują na znaczne zmiany w sytuacji finansowej byłego monopolisty rynku telekomunikacyjnego. Grupa Orange, według przytoczonych danych, $z$ każdym rokiem osiągała coraz gorszy wynik finansowy.

\section{Metody}

W artykule zastosowano różne źródła i metody badawcze. W części teoretycznej wykorzystano opracowania zwarte. Materiał empiryczny obejmuje raporty i sprawozdania Orange Polska (2012a-2017a). Wśród użytych metod badawczych wymienić można analizę finansową i techniczno-ekonomiczną w części empirycznej artykułu.

\section{Wyniki badania}

\subsection{Analiza finansowa Grupy Kapitałowej Orange Polska w latach 2011-2016}

Analiza finansowa jest jednym $z$ dwóch podstawowych elementów składowych analizy ekonomicznej. Definiowana jest jako „sposób rozumowania wymagany dla zrozumienia działalności gospodarczej przedsiębiorstwa, jego branży, przedstawionych w sprawozdaniu finansowym wyników oraz różnych rodzajów ryzyka" (Patterson, 2015, s. 24).

Głównym przedmiotem zainteresowania $\mathrm{w}$ dokonywaniu analizy są przede wszystkim 
sprawozdania finansowe, które są podstawowymi i najbardziej wyczerpującymi dokumentami, charakteryzującymi sytuację finansową danego przedsiębiorstwa (Cymerman, 2017, s. 44). W przypadku Grupy Orange dokumentami, na podstawie których tworzy się analizę, są skonsolidowane raporty roczne. Przedstawią one dane spółki dominującej oraz spółek od niej zależnych wszystkich szczebli w taki sposób, jakby grupa kapitałowa stanowiła jedną jednostkę (Gołębiowski i Tłaczała, 2009, s. 18). Grupę Orange stanowi Orange Polska oraz jej spółki zależne, którymi są (Orange Polska, 2017a, s. 9):

- Integrated Solutions,

- TP TelTech,

- Telefony Podlaskie,

- Orange Retail,

- Orange Real Estate,

- Orange Szkolenia,

- Pracownicze Towarzystwo Emerytalne Orange,

- Fundacja Orange,

- Telekomunikacja Polska,

- Orange Customer Service,

- TP Invest,

- TPSA Eurofinance France.

$\mathrm{Na}$ analizę finansową składa się: wstępna i rozwinięta analiza bilansu, rachunku zysków i strat, rachunku przepływów pieniężnych, źródeł przychodów i kierunków ich rozdysponowania, analiza wyniku finansowego i czynników go kształtujących oraz analiza wskaźnikowa w takich obszarach, jak: płynność finansowa, zadłużenie, rentowność, sprawność działania (Jachna i Sierpińska, 2004, s. 15). W niniejszym artykule omówione zostaną jedynie te $z$ wyżej wymienionych obszarów, które odpowiednio obrazują zmianę sytuacji finansowej Grupy Orange po zakończonym procesie jej prywatyzacji.

\subsubsection{Analiza bilansu Grupy Kapitałowej Orange Polska w latach 2011-2016}

Bilans jest najbardziej podstawową częścią sprawozdania finansowego, który daje obraz sytuacji majątkowo-kapitałowej przedsiębiorstwa (Jachna i Sierpińska, 2004, s.67). Jednym $z$ jego elementów jest zestawienie ukazujące wartość poszczególnych składników przedsiębiorstwa. Poziom aktywów w latach 20112016 dla Grupy Orange został przedstawiony w tabeli 1.

$Z$ roku na rok wartość aktywów Grupy Orange malała, z wyjątkiem 2016 roku. W 2011 roku łączna wartość aktywów wynosiła $28219 \mathrm{mln}$ PLN, w ostatnim $z$ analizowanych lat natomiast $22588 \mathrm{mln}$ PLN.

Zmiany pozycji aktywów, jakie następowały $w$ analizowanych latach, najlepiej obrazuje dynamika aktywów Grupy Orange, która została zaprezentowana $w$ tabeli 2 . W analizowanych latach, $z$ roku na rok malała wartość rzeczowych aktywów trwałych, która mając duży udział w całkowitej wartości aktywów Grupy Orange, powodowała jej spadek. Inne składniki majątku w analizowanych latach podlegały znacznym wahaniom.

W 2012 roku największemu spadkowi (o 57,2 p.p.), uległa wartość aktywów obrotowych. Spośród nich, największy spadek (o ponad połowę), dotyczył wartości inwestycji krótkoterminowych. Było to spowodowane spadkiem wartości środków pieniężnych i ekwiwalentów środków pieniężnych. Wśród aktywów trwałych, zdecydowany spadek, $\mathrm{w}$ porównaniu do poprzedniego roku, odnotowany został $\mathrm{w}$ przypadku wartości inwestycji długoterminowych, co z kolei było spowodowane spadkiem wartości instrumentów pochodnych.

W 2013 roku drastycznemu zmniejszeniu uległa wartość inwestycji długoterminowych, które stanowiły tylko 9,0\% ich wartości z roku poprzedniego. Było to spowodowane sprzedażą znacznej części instrumentów pochodnych przez Grupę Orange. Wśród aktywów bieżących, zauważalny spadek dotyczył wartości inwestycji krótkoterminowych. Znacząco zaś wzrosła wartość krótkoterminowych rozliczeń międzyokresowych, które osiągnęły poziom 131,0\% ich wartości z 2012 roku. Łączna wartość aktywów stanowiła zaś tylko 94,4\% wartości z roku poprzedniego.

W 2014 roku nastąpił kilkukrotny wzrost wartości inwestycji długoterminowych $\mathrm{w}$ stosunku do roku poprzedniego. Było to jednak 
głównie spowodowane niską wartością tego składnika bilansu $\mathrm{w}$ roku poprzednim. Znacząco (o ponad 12,0 p.p.), wzrosła wartość aktywów obrotowych, do czego w dużym stopniu przyczynił się wzrost wartości należności krótkoterminowych, a konkretnie należności handlowych. Nie zatrzymało to jednak dalszego spadku całkowitej wartości aktywów.

W 2015 roku, w odniesieniu do poprzedniego roku, wzrosły wartości należności i inwestycji długoterminowych (o ponad 50,0 p.p.). Nastąpił również wzrost wartości aktywów obrotowych (o 12,1 p.p.), w tym zapasów, należności krótkoterminowych oraz krótkoterminowych rozliczeń międzyokresowych. Łączna wartość aktywów spadła dzięki temu tylko o 2,0 p.p. w odniesieniu do roku poprzedniego.

Spadkowa tendencja dotycząca całkowitej wartości aktywów, została zatrzymana dopiero w 2016 roku. Największy wpływ miał na to wzrost poziomu wartości niematerialnych i prawnych (o ponad 13,0 p.p.), ponieważ składnik ten miał znaczący udział w strukturze majątku Grupy Orange we wszystkich, analizowanych latach (tabela 3.).

W całym, analizowanym okresie aktywa trwałe stanowiły większość majątku przedsiębiorstwa. W 2012 roku ich udział w strukturze aktywów zwiększył się o 9,1 p.p., do poziomu 90,9\% aktywów, z kolei w kolejnych latach nieznacznie zmalał, do poziomu $89,2 \%$ całej sumy bilansowej. Składnikiem majątku przedsiębiorstwa, który wyróżniał się na tle pozostałych, były rzeczowe aktywa trwałe. Ich udział w strukturze aktywów we wszystkich, analizowanych latach, z wyjątkiem 2016 roku, utrzymywal się na poziomie przekraczającym $50,0 \%$. Bardzo znaczący i rosnący udział w strukturze majątku miały również wartości niematerialne i prawne.

Wśród części aktywów bieżących, nieznacznym wzrostem charakteryzował się udział należności krótkoterminowych, który wzrósł do poziomu 8,1\% w 2016 roku. Z kolei udział inwestycji krótkoterminowych $w$ majątku, spadł znacząco w 2012 roku (o 11,0 p.p.), do poziomu $0,8 \%$ i nieznacznie wzrósł w ko- lejnych latach do poziomu 2,0\% w 2015 roku, jednak w 2016 roku znów spadł o 1,5 p.p.

Aktywa są jedną stroną bilansu finansowego, drugą zaś stanowią pasywa. Źródła finansowania Grupy Orange w analizowanych latach zaprezentowane zostały w tabeli 4.

Grupa Orange do 2015 roku finansowana była głównie kapitałem własnym. W 2016 roku znacznie wzrosły jednak jej zobowiązania długoterminowe. Dynamika pasywów przedstawiona została w tabeli 5 .

W analizowanym okresie, łączna wartość pasywów Grupy Orange z roku na rok malała, z wyjątkiem 2016 roku. W 2012 roku doszło do spadku wartości kapitału własnego (o 9,6 p.p.), na co przełożył się spadek zatrzymanego zysku. Znacznemu zmniejszeniu uległa również wartość kapitału obcego, wśród którego zwiększeniu uległa wartość zobowiązań krótkoterminowych, a dużemu spadkowi (o 18,0 p.p.), wartość zobowiązań długoterminowych. Spadek ten był przede wszystkim efektem zmniejszenia się zobowiązań finansowych (o ponad $1000 \mathrm{mln}$ PLN).

W 2013 roku wartość kapitału własnego uległa zmniejszeniu o 1,7 p.p., co było głównie efektem niższych zysków zatrzymanych. Spadkowi uległ również poziom kapitałów obcych, na co przełożył się głównie spadek wartości zobowiązań długoterminowych (o 44,2 p.p.). Z kolei zwiększeniu uległa wartość zobowiązań krótkoterminowych - do poziomu $119,4 \%$ w stosunku do roku poprzedniego.

W 2014 roku wartość pasywów znów zmalała (o 3,1 p.p.), co było głównie skutkiem zmniejszenia się wartości kapitału obcego (o 4,2 p.p.), a w tym zobowiązań krótkoterminowych o (41,5 p.p.). Zwiększyła się natomiast (o 88,7 p.p.), wartość zobowiązań długoterminowych. Wartość kapitału własnego zmniejszyła się nieznacznie (o 1,8 p.p.).

W 2015 roku zysk zatrzymany zmniejszył się o 5,8 p.p., co było głównym powodem zmniejszenia wartości kapitału własnego (o 3,4 p.p.). Wartość kapitału obcego również uległa nieznacznemu zmniejszeniu (o 0,3 p.p.). Największy spadek poziomu, w stosunku do poprzedniego roku, odnotowany został 
w przypadku zobowiązań długoterminowych, których wartość zmalała o 12,4 p.p.

W 2016 roku (o ponad 98,0 p.p.), wzrosła wartość zobowiązań długoterminowych. Tak znaczny wzrost był skutkiem zaciągnięcia nowych pożyczek przez Grupę Orange. Całkowita wartość jej zobowiązań wzrosła zaś o 30,0 p.p., spadł natomiast poziom kapitał własnego (o 16,4 p.p.).

Udział poszczególnych źródeł finansowania w całkowitej wartości pasywów Grupy Orange został przedstawiony w tabeli 6 .

Struktura źródeł finansowania Grupy Orange $\mathrm{w}$ analizowanym okresie nie uległa zasadniczej zmianie, $z$ wyjątkiem 2016 roku. Cały czas dominował $\mathrm{w}$ niej kapitał własny, który zawsze stanowił ponad połowę wartości pasywów. Grupa Orange była więc w większości finansowana własnymi środkami, w związku z tym jej stabilność finansowa była wysoka. W strukturze kapitału własnego, kluczowe znaczenia miał kapitał podstawowy, który oscylował między 14,0\% a $18,0 \%$ udziałem w całej strukturze majątku oraz zyski zatrzymane, które do 2015 roku zawsze posiadały ponad 30,0\% udział. Wśród zobowiązań, największe znaczenie w strukturze majątku miały zobowiązania finansowe wobec pożyczkodawców oraz zobowiązania handlowe wobec dostawców, zarówno długo-, jak i krótkoterminowe. Każdy rok charakteryzował się odmienną strukturą w tym względzie, mianowicie $w$ niektórych $z$ analizowanych lat to udział wartości zobowiązań krótkoterminowych był większy, a innym razem większy udział w całkowitej wartości pasywów miały zobowiązania długoterminowe. W 2016 roku nastąpił znaczny wzrost udziału tych drugich (o 16,9 p.p.), co spowodowało, że kapitał obcy, jedyny raz $w$ analizowanym okresie, osiaggnął ponad 50,0\% udział $\mathrm{w}$ całkowitej wartości pasywów.

Podsumowując analizę bilansu, można stwierdzić, że po zakończonym procesie prywatyzacji Grupy Orange, wartość jej majątku $z$ roku na rok malała, $z$ wyjątkiem 2016 roku. Wynikało to $z$ nasilenia się walki konkurencyjnej w branży telekomunikacyjnej i szukania oszczędności przez to przedsiębiorstwo. Były monopolista na polskim rynku telekomunikacyjnym był do 2015 roku głównie finansowany kapitałem własnym, jednak w 2016 roku, pod wpływem zaciągnięcia przez niego nowych pożyczek, większy udział zyskał kapitał obcy.

\subsubsection{Analiza rachunku zysku i strat Grupy Kapitałowej Orange Polska w latach 2011-2016}

Kluczowym zestawieniem dla każdego przedsiębiorstwa jest rachunek zysków i strat, gdyż przedstawia on jego dokonania za dany rok, zestawiając razem przychody i koszty ich osiągnięcia (Dudycz, 1999, s. 36). W tabeli 7. został zaprezentowany rachunek zysków i strat dla Grupy Orange, natomiast w tabeli 8. jego dynamika $w$ analizowanych latach.

Sytuacja finansowa Grupy Orange w analizowanych latach była $z$ każdym rokiem gorsza. Jej zysk netto z roku na rok malał, a w 2016 roku osiągnął znaczną wartość ujemną $(-1$ $746 \mathrm{mln}$ PLN).

W 2012 roku wynik ze sprzedaży uległ zmniejszeniu o 21,1 p.p., z kolei zmniejszenie zysku operacyjnego (o 29,1 p.p.) oraz wyniku $z$ działalności gospodarczej (o 43,1 p.p.), spowodowały zmniejszenie wyniku netto przedsiębiorstwa do poziomu $44,6 \%$, w porównaniu do poprzedniego roku.

W 2013 roku sytuacja znacznie się pogorszyła, wynik ze sprzedaży zmniejszył się o 12,1 p.p., dużemu zmniejszeniu (o 49,9 p.p.), uległ zysk z działalności operacyjnej. Ogromny spadek (o 69,5 p.p.), dotyczył wyniku z działalności gospodarczej, jak również zysku brutto. $Z$ kolei zdecydowanie mniejszy podatek dochodowy, doprowadził do ustalenia całkowitego wyniku netto na poziomie $34,4 \%$, w porównaniu do 2012 roku.

W 2014 roku nastąpiło polepszenie sytuacji finansowej przedsiębiorstwa. Co prawda wynik ze sprzedaży spadł o 2,5 p.p., jednak znaczne wzrosty $\mathrm{w}$ pozostałych dziedzinach działalności przedsiębiorstwa, były powodem wzrostu wyniku brutto o 87,4 p.p. Wzrastający zysk brutto doprowadził również do wzrostu podatku dochodowego (o 287,5 p.p.), co skutkowało ukształtowaniem się zysku 
netto na poziomie $182,0 \%$ względem roku poprzedniego.

W 2015 roku zysk ze sprzedaży spadł o 12,9 p.p., zdecydowanie spadł również wynik $z$ działalności operacyjnej (o 42,0 p.p.). Zysk z działalności gospodarczej zaś wyniósł tylko 48,4\% wartości z roku 2014. Spadki, we wszystkich dziedzinach działalności Grupy Orange, wpłynęły na spadek zysku netto o 52,6 p.p., który osiągnął wartość $254 \mathrm{mln}$ PLN.

2016 rok był najgorszym $z$ analizowanych lat dla Grupy Orange. Osiągnęła ona ogromne straty (ponad $1746 \mathrm{mln}$ PLN). Było to przede wszystkim spowodowane odpisem wartości aktywów w wysokości 1792 mln PLN, który był rezultatem przeszacowania wartości oczekiwanych, przyszłych przepływów pieniężnych. Przychody ze sprzedaży w 2016 roku zmalały o 2,5 p.p. i utrzymały negatywną tendencję ze wcześniejszych, analizowanych lat.

Podsumowując analizę rachunku zysków i strat można stwierdzić, że przychody ze sprzedaży operatora o znaczącej pozycji na polskim rynku telekomunikacyjnym, po zakończonym procesie jego prywatyzacji, wykazywały tendencję spadkową $w$ analizowanych latach. Wynikało to z utraty części rynku na rzecz operatorów alternatywnych, jak również coraz niższych cen samych usług telekomunikacyjnych. Wraz ze spadkiem przychodów ze sprzedaży, malał również wynik finansowy Grupy Orange. Wyjątkiem był 2014 rok, jednak było to skutkiem jednorazowego działania operacyjnego podjętego przez grupę (sprzedaż Wirtualnej Polski SA), a nie polepszenia jej sytuacji na rynku. W 2016 roku Grupa Orange zanotowała ogromną stratę wynoszącą $1746 \mathrm{mln}$ PLN, co wynikało przede wszystkim ze wzrostu pozostałych kosztów operacyjnych (o ponad 40,0 p.p.).

\subsubsection{Analiza wskaźnikowa Grupy Kapitałowej Orange Polska w latach 2011-2016}

Ważnym elementem $\mathrm{w}$ analizie finansowej każdego przedsiębiorstwa jest analiza wskaźnikowa. Dostarcza ona informacje o jego sytuacji finansowej i rezultatach działalności na podstawie grupy logicznie ze sobą powiąza- nych wskaźników (Gabrusewicz, 2002, s. 29). W niniejszym artykule zostaną wykorzystane te grupy wskaźników, które odpowiednio ukazują zmiany, jakie dokonały się w sytuacji finansowej Grupy Orange po zakończonym procesie jej prywatyzacji.

$\mathrm{W}$ pierwszej kolejności przeanalizowane zostaną wskaźniki płynności przedsiębiorstwa, czyli zdolności do terminowego regulowania zobowiązań. Poziom wybranych wskaźników dla Grupy Orange w latach 2011-2016 został przedstawiony $w$ tabeli 9.

Żaden $z$ analizowanych wskaźników opisujących płynność finansową Grupy Orange nie osiągnął optymalnego poziomu (powyżej jedności) w omawianych latach. Najwyższy ich poziom przedsiębiorstwo osiągało w 2011 roku. W kolejnych latach podlegał on wahaniom. Tak niski poziom wskaźników płynności świadczył o niewielkiej zdolności przedsiębiorstwa do regulowania bieżących zobowiązań, Grupa Orange miała problemy $z$ regulowaniem płatności $w$ terminie.

Istotne informacje na temat wartości zaciągniętych kredytów i pożyczek, w odniesieniu do wszystkich źródel finansowania przedsiębiorstwa, przekazują wskaźniki dotyczące zadłużenia, które w przypadku Grupy Orange zaprezentowane zostały w tabeli 10.

Wybrane wskaźniki opisujące zadłużenie $\mathrm{w}$ analizowanych latach, osiągały poziom poniżej uznawanego za graniczny, $z$ wyjątkiem 2016 roku, gdy wskaźnik zadłużenia kapitału własnego przekroczył optymalną wartość wynoszącą jeden. Oznacza to, że Grupa Orange nie była zadłużona w stopniu, który zagrażałby jej działaniu. Do 2015 roku finansowana była głównie kapitałem własnym, jednak w 2016 roku zaczęła $w$ większym stopniu korzystać $z$ kapitału obcego, co wynikało częściowo z konieczności sfinansowania straty, jaką zanotowało przedsiębiorstwo w tamtym roku.

Ważną informacją dla przedsiębiorstwa jest zysk, jaki generuje zaangażowany kapitał, a którą przekazują wskaźniki rentowności. W tabeli 11. przedstawiony został ich poziom dla Grupy Orange w analizowanych latach.

Poziom wskaźników rentowności wskazuje, że majątek Grupy Orange był inwe- 
stowany niezbyt skutecznie. Wskaźnik rentownościaktywów (returnonassets - ROA) i wskaźnik rentowności kapitału własnego (return on equity - ROE), w analizowanych latach, charakteryzowały się tendencją spadkową, a w 2016 roku osiągnęły ujemny poziom. Oznacza to, że z zainwestowanych aktywów i kapitału własnego, przedsiębiorstwo osiągnęło straty. Również efektywność sprzedaży Grupy Orange w analizowanych latach była bardzo niska, czyli generowała ona mały zysk $z$ osiągniętych przychodów ze sprzedaży, a w 2016 roku nawet osiągnęła straty. Na podstawie danych zawartych $\mathrm{w}$ tabeli 11 . można uznać, że po zakończonym procesie prywatyzacji byłego państwowego monopolisty branży telekomunikacyjnej, jego sytuacja pod względem rentowności $z$ roku na rok była coraz gorsza.

$\mathrm{Na}$ podstawie analizy wskaźnikowej Grupy Orange można wyciągnąć wniosek, że z każdym rokiem jej sytuacja, pod różnym aspektami, była coraz trudniejsza. Zdecydowanie najgorszym dla niej rokiem, ze względu na poziom wszystkich, omawianych wskaźników, był 2016 rok, co jest zrozumiałe, biorąc pod uwage fakt ogromnej straty finansowej, jaką zanotowało wtedy to przedsiębiorstwo telekomunikacyjne.

\subsection{Analiza techniczno-ekonomiczna Grupy Kapitałowej Orange Polska w latach 2011-2016}

Drugim, podstawowym działem analizy ekonomicznej jest analiza techniczno-ekonomiczna. Jej celem jest określenie czynników mających wpływ na sytuację finansową przedsiębiorstwa i siły ich oddziaływania. Głównym zadaniem analizy techniczno-ekonomicznej jest ocena poszczególnych segmentów działań gospodarczych, podejmowanych przez przedsiębiorstwo, czyli: ilości i asortymentu produkcji, metod jej wytwarzania, wyposażenia technicznego, zaopatrzenia materiałowego i stopnia wykorzystania materiałów, zatrudnienia, płac i wydajności pracy (Jachna i Sierpińska, 2004, s. 15). W niniejszym artykule zostaną przedstawione te obszary usługowej działalności Grupy Orange, na których zmiany miał wpływ zakończony proces jej prywatyzacji.

\subsubsection{Analiza zatrudnienia Grupy Kapitałowej Orange Polska w latach 2011-2016}

Zatrudnienie w Grupie Orange w analizowanych latach $z$ roku na rok malało (wykres 1.). W 2011 roku wynosiło ono 23805 pracowników, zaś w 2016 roku już tylko 15 537. Wraz $z$ trwającym procesem liberalizacji branży telekomunikacyjnej, Grupa Orange dostosowywała się do coraz trudniejszych dla niej warunków rynkowych, zmniejszając zatrudnienie z 68 tys. etatów w 2001 roku (co było dziedzictwem jej poprzedniej roli jako państwowego, narodowego operatora telekomunikacyjnego), do poziomu odpowiadającego realiom rynku telekomunikacyjnego w 2011 roku i w latach następnych (Orange Polska, 2016b, s. 41).

Dynamika tych zmian, w analizowanych latach, przedstawiona została na wykresie 2. $Z$ roku na rok zatrudnienie w Grupie Orange malało, jednak zawsze w różnym stopniu. Największą jego redukcję, dawny monopolista branży telekomunikacyjnej, dokonal w 2013 roku, gdy spadło ono o 11,0 p.p. w stosunku do roku poprzedniego. Plany dotyczące zatrudnienia na przyszłe lata, przewidywały dalsze zmniejszanie zatrudnia tak, aby Grupa Orange mogła coraz efektywnej rywalizować z coraz większą konkurencją w branży telekomunikacyjnej. Optymalizacja zatrudnienia wynikała z chęci zwiększenia efektywności, co w efekcie przyniosło wymierne oszczędności, także w zakresie kosztów pracy (tabela 12.).

Jak można zauważyć na podstawie danych $z$ tabeli 12 ., łączne zobowiązania $z$ tytułu świadczeń pracowniczych wykazywały tendencję spadkową, z małymi odstępstwami w 2012 i 2014 roku. Wynikało to z faktu, że co prawda ograniczenie zatrudnienia zmniejszyło fundusz płac, lecz powodowało również powstanie dodatkowych kosztów odprawy pracowniczej, które z 2011 roku na 2012 rok wzrosły o $61 \mathrm{mln}$ PLN, zaś z 2013 roku na 2014 rok wzrosły o $24 \mathrm{mln}$ PLN. W latach 2015 i 2016 były one jednak coraz niższe, 
co również miało wpływ na to, że w 2016 roku łączne koszty Grupy Orange na rzecz pracowników, osiągnęły najniższą wartość we wszystkich, analizowanych latach (332 $\mathrm{mln}$ PLN). Dynamika ich zmian została przedstawiona na wykresie 3.

W 2012 i 2014 roku zobowiązania $z$ tytułu świadczeń pracowniczych nieznacznie wzrosły w odniesieniu do poprzednich lat. $\mathrm{W}$ pozostałych latach dynamika ich zmian była spadkowa. Największe zmniejszenie wartości zobowiązań z tytułu świadczeń pracowniczych Grupy Orange nastąpiło w 2016, gdy ich poziom osiągnął tylko $75,6 \%$ wartości $z$ roku poprzedniego.

Konkurencja ze strony operatorów alternatywnych, w warunkach zliberalizowanej branży telekomunikacyjnej, była z każdym rokiem coraz większa. W takiej sytuacji Grupa Orange, działając jako $\mathrm{w}$ pełni prywatne przedsiębiorstwo, była zmuszana do ciągłego szukania oszczędności, co wiązało się ze stałą redukcją zatrudnienia.

\subsubsection{Analiza wydajności pracy Grupy Kapitałowej Orange Polska w latach 2011-2016}

Wraz $z$ redukcją zatrudnienia rosła indywidualna wydajność pracy pracownika Grupy Orange (wykres 4.). Wydajność pracy w Grupie Orange znacząco rosła $z$ roku na rok. Było to zjawisko bardzo pozytywne, ponieważ świadczyło o zwiększeniu efektywności posiadanych zasobów $\mathrm{w}$ postaci czynnika ludzkiego. Na takie kształtowanie się tego wskaźnika miała wpływ reorganizacja pracy $\mathrm{w}$ przedsiębiorstwie, poprzez zmniejszenie kadry pracowniczej. Na wykresie 4. zobrazowane zostały przychody generowane przez jednego pracownika $w$ analizowanych latach. W najlepszym pod tym względem 2016 roku, było to ponad 740 tys. PLN.

Dynamika zmian indywidualnej wydajności pracy w Grupie Orange przedstawiona została na wykresie 5. Do 2015 roku miała tendencje rosnącą. W 2016 roku wzrost dynamiki zmian indywidualnej wydajności pracy był nieznacznie mniejszy, gdyż osiągnął poziom 4,1 p.p.
Wydajność pracy rosła wraz ze spadkiem zatrudnienia, co wskazuje na to, że w Grupie Orange efektywniej zaczęto wykorzystywać kapitał ludzki. Jest to jeden $z$ nielicznych, pozytywnych aspektów liberalizacji branży telekomunikacyjnej oraz prywatyzacji jej byłego monopolisty dla Grupy Orange.

\subsubsection{Analiza wynagrodzeń Grupy Kapitałowej Orange Polska w latach 2011-2016}

W związku z redukcją zatrudnienia, również wydatki na wynagrodzenia pracownicze $z$ roku na rok malały (wykres 6.). Redukcja wydatków miała pomóc w zahamowaniu tendencji spadkowej wyniku finansowego Grupy Orange.

Zmniejszeniu wydatków płacowych Grupy Orange towarzyszyło zwiększenie średniego, rocznego wynagrodzenia przypadającego na jednego pracownika (wykres 7.). Kształtowało się ono w analizowanych latach na wysokim i rosnącym poziomie. Związane było to $z$ nasileniem się walki konkurencyjnej wewnątrz sektora telekomunikacyjnego oraz rok rocznym wzrostem wydajności pracy pracowników Grupy Orange. W 2016 roku średnie, roczne wynagrodzenie jednego pracownika wyniosło ponad 98 tys. PLN, czyli osiągnęło najwyższą wartość $\mathrm{w}$ omawianych latach.

Dynamika zmian wynagrodzenia per capita przedstawiona została na wykresie 8 . Największy wzrost średniego, rocznego wynagrodzenia przypadającego na jednego pracownika Grupy Orange nastąpił w 2013 roku (o 9,3 p.p.). Najmniejszy przyrost nastąpił natomiast w 2014 i 2015 roku.

Liberalizacja branży telekomunikacyjnej, jak również proces prywatyzacji Grupy Orange, zmusiły ten podmiot do ciągłego zwiększania wynagrodzenia pracowników. Operatorzy alternatywni, mając coraz większy udziały, mogli oferować coraz lepsze warunki zatrudnienia. Grupa Orange w takiej sytuacji, również musiała $z$ każdym rokiem zwiększać wynagrodzenie tak, aby przyciągać do siebie najbardziej wydajnych pracowników. 
4.2.4. Analiza sprzedaży Grupy Kapitałowej Orange Polska w latach 2011-2016

W Grupie Orange, jak zostało już wspomniane w Sekcji 1., usługi są dzielone na stacjonarne i komórkowe. W tabeli 13. zostały zestawione przychody ze sprzedaży usług $z$ tych dwóch obszarów działalności analizowanego podmiotu.

Łączne przychody ze sprzedaży usług Grupy Orange, $z$ roku na rok były coraz nizsze, w 2011 roku wynosity one $14922 \mathrm{mln}$ PLN, zaś w 2016 roku osiągnęły najniższą wartość w omawianych latach (11 $538 \mathrm{mln}$ PLN). Dynamika tych zmian została przedstawiona w tabeli 14.

Do 2014 roku dynamika zmian przychodów z usług komórkowych Grupy Orange była malejąca, mimo ciągłego wzrostu przychodów ze sprzedaży sprzętu do usług komórkowych. Wpływ na taką sytuację miał zarówno spadek przychodów z usług detalicznych, który był wynikiem nasilającej się walki konkurencyjnej wewnątrz sektora, jak i spadek przychodów z usług hurtowych. Dopiero w 2015 roku, wartość przychodów z usług komórkowych dorównała poziomowi $z$ poprzedniego roku, a w 2016 rok wzrosła (o 4,6 p.p.). Było to wynikiem zwiększania przychodów ze sprzedaży usług hurtowych, jak również ciągłego utrzymywania tendencji wzrostowej w odniesieniu do przychodów ze sprzedaży sprzętu do usług komórkowych, co wynikało z coraz większego popytu na tego typu usługi.

Przychody ze sprzedaży usług stacjonarnych $\mathrm{w}$ analizowanych latach znacznie malały, w graniach 7,0-8,0 p.p. rocznie. Największy na to wpływ mial przede wszystkim bardzo znaczny spadek przychodów z usług wąskopasmowych, co z kolei było głównie efektem migracji klientów z sieci stacjonarnej do komórkowej.

Łączne przychody ze sprzedaży usług Grupy Orange natomiast z roku na rok malały. Największy ich spadek miał miejsce w 2012 roku, gdy osiągnęły tylko 91,4\% ich wartości $z$ roku poprzedniego.

Struktura przychodów ze sprzedaży usług Grupy Orange przedstawiona została w tabeli
15. Jeszcze w 2011 roku większy udział, w całości przychodów Grupy Orange, miały usługi stacjonarne, jednak od 2012 roku większe przychody uzyskiwane były już z usług komórkowych, których znaczenie od 2013 roku stale rosło. W 2016 roku ich udział wyniósł ponad $55,0 \%$ przychodów ogółem. Spośród usług telefonii ruchomej, zdecydowanie największy (ponad 37,0\%) udział w strukturze przychodów Grupy Orange, we wszystkich analizowanych latach, miały usługi detaliczne. Wynika to $z$ faktu, że był to główny kierunek sprzedaży. Spośród usług stacjonarnych, największy udział miały natomiast usługi wąskopasmowe, jednak $z$ roku na rok był on coraz niższy. Było to skutkiem zastępowania ich przez bardziej zaawansowane technologicznie usługi szerokopasmowe, telewizji i transmisji głosu przez Internet, których udział z kolei w całości przychodów Grupy Orange z roku na rok rósł.

Po zakończonym procesie prywatyzacji Grupy Orange, któremu towarzyszyła liberalizacja branży telekomunikacyjnej, $z$ roku na rok jej łączne przychody ze sprzedaży usług zmniejszały się. W 2015 roku zdołała ona jednak zatrzymać spadkową tendencję przychodów ze sprzedaży usług komórkowych, których znaczenie jest coraz większe, ze względu na ich udział w całkowitych przychodach. Daje to pewne, pozytywne perspektywy rozwoju Grupy Orange.

\section{Zakończenie}

Zmiany, jakie dokonywały się na poszczególnych rynkach telekomunikacyjnych w Polsce pod wypływem zakończonego procesu prywatyzacji TP SA i trwającego procesu liberalizacji branży telekomunikacyjnej, znalazły swoje odzwierciedlenie $w$ wynikach finansowych Grupy Orange. Analiza bilansu wykazała, że z wyjątkiem 2016 roku, wartość majątku byłego monopolisty polskiej branży telekomunikacyjnej z roku na rok malała. Jego przychody ze sprzedaży również charakteryzowały się tendencją spadkową, co z kolei powodowało rok roczne zmniejszanie się poziomu wyniku finansowego Grupy Orange, 
który w 2016 roku osiągnął znaczną wartość ujemną.

$\mathrm{Na}$ podstawie przeprowadzonej analizy wskaźnikowej Grupy Orange można stwierdzić, że z każdym rokiem jej sytuacja finansowa się pogarszała. Miała ona m.in. coraz większe problemy z regulowaniem zobowiązań bieżących. Operator o pozycji znaczącej $\mathrm{w}$ polskiej branży telekomunikacyjnej nie wykazywał zbyt wysokiego poziomu zadłużenia, jednak wskaźniki określające jego poziom, z każdym rokiem ulegały pogorszeniu. Uzyskany poziom wskaźników rentowności, we wszystkich analizowanych latach, oznacza niski zwrot $z$ zainwestowanego kapitału. Ich poziom ponadto wykazywał się tendencją spadkową $\mathrm{w}$ analizowanym okresie.

Pewne, pozytywne aspekty procesu prywatyzacji TP SA i liberalizacji branży telekomunikacyjnej dla Grupy Orange wykazała analiza techniczno-ekonomiczna. W nowej sytuacji rynkowej, były monopolista branży telekomunikacyjnej w Polsce, był co prawda zmuszony dokonywać konsekwentnej, znacznej redukcji zatrudnienia, jednak rosła $w$ tym okresie również indywidualna wydajność pracy, co powodowało z kolei wzrost średniego, rocznego wynagrodzenia pracowników.

Analiza wyników finansowych Grupy Orange w omawianym okresie wykazała, że prywatyzacja TP SA wywarła negatywny wpływ na sytuację finansową Grupy Orange. Kluczowe znaczenie miało to, że procesowi prywatyzacji TP SA towarzyszył proces liberalizacji branży telekomunikacyjnej, przez co TP SA straciła swoją pozycję monopolisty branży, a w związku z tym również znaczne udziały w branży telekomunikacyjnej.

\section{Bibliografia}

Babis, H., i Czaplewski, R. (2011). Usługi telekomunikacyjne. W: H. Babis, i K. Flaga-Gieruszyńska (red.), Rynek ustug telekomunikacyjnych. Warszawa: Wolters Kluwer Business.

Begg, D., Fischer, S., i Dornbusch, R. (2007). Mikroekonomia. Warszawa: PWE.
Budziewicz-Guźlecka, A. (2011). Przekształcenia polskiego rynku usług telekomunikacyjnych. W: H. Babis, i K. Flaga-Gieruszyńska (red.), Rynek ustug telekomunikacyjnych. Warszawa: Wolters Kluwer Business.

Cymerman, A. (2017). Analiza finansowa jako narzędzie wspomagające proces zarządzania przedsiębiorstwem. Pobrane 18.04.2017 z http://www. wspia.eu.

Dudycz, T. (1999). Analiza finansowa. Wrocław: AE Wrocław.

Dyrektywa 96/19/WE z dnia 13 marca $1996 \mathrm{r}$. o konkurencji na rynkach telekomunikacyjnych (Dz.U. L 74 z 22.3.1996).

Gabrusewicz, W. (2002). Podstawy analizy finansowej. Warszawa: PWE.

Gołębiowski, G., i Tłaczała, A. (2009). Analiza finansowa $w$ teorii i $w$ praktyce. Warszawa: Difin.

Jachna, T., i Sierpińska, M. (2004). Ocena przedsiębiorstwa wedtug standardów światowych. Warszawa: PWN.

Kaczmarczyk, P. (2015). Analiza rozwoju rynku telefonii mobilnej w Polsce w latach 2002-2013. Kwartalnik Kolegium Ekonomiczno-Spotecznego Studia i Prace, 1(21).

Orange Polska. (2012a-2017a). Skonsolidowany raport roczny za lata 2011-2016. Pobrane 23.04.2017 z http://www.orange-ir.pl.

Orange Polska. (2016b). Raport roczny za 2015 rok. Pobrane 21.04.2017 z http://www.orange-ir.pl.

Patterson, R. (2015). Kompendium terminów $z z a$ kresu finansów po polsku i angielsku. Warszawa: Ministerstwo Finansów.

Raczyński, M. (2006). Reforma sektora telekomunikacyjnego. W: D. Kopycińska (red.), Regulacyjna rola państwa we wspótczesnej gospodarce. Szczecin: Printgroup.

UKE. (2011). Raport o stanie rynku telekomunikacyjnego w Polsce w 2010 roku. Pobrane 27.02.2017 $z$ https://www.uke.gov.pl.

Ustawa $z$ dnia 16 lipca 2004 r. Prawo telekomunikacyjne (Dz.U. $2004 \mathrm{nr} 171$ poz. 1800).

Ustawa z dnia 21 lipca 2000 r. Prawo telekomunikacyjne (Dz.U. $2000 \mathrm{nr} 73$ poz. 852).

Ustawa z dnia 23 listopada 1990 r. o łączności (Dz.U. $1990 \mathrm{nr} 86$ poz. 504).

Zygadlewicz, M. (2017). Prywatyzacja na rynku telekomunikacyjnym $w$ Polsce a sytuacja finansowa Grupy Kapitałowej Orange Polska. Nieopublikowana praca licencjacka, Uniwersytet Mikołaja Kopernika, Torun. 
Informacje uzupetniające

Wkład autorski: autor zaakceptował ostateczną wersję artykułu.

Źródła finansowania: artykuł został w całości sfinansowany ze środków własnych autora.

Uwagi: wyniki badania byly zaprezentowane $w$ innej formie, tj. pracy licencjackiej Zygadlewicz (2017). 
Aneks

Tabela 1 .

Wartość aktywów Grupy Orange w latach 2011-2016 (w mln PLN)

\begin{tabular}{llrrrrrr}
\hline \multicolumn{1}{c}{ Lp. Aktywa } & \multicolumn{1}{c}{2011} & 2012 & 2013 & 2014 & 2015 & 2016 \\
\hline I & aktywa trwałe & 23091 & 21945 & 20864 & 20026 & 19322 & 20170 \\
1 & wartości niematerialne i prawne & 6971 & 6974 & 7021 & 7155 & 6950 & 7869 \\
2 & rzeczowe aktywa trwałe & 14912 & 13935 & 12768 & 11715 & 11025 & 10678 \\
3 & należności długoterminowe & - & - & - & 138 & 210 & 433 \\
4 & inwestycje długoterminowe & 309 & 162 & 13 & 84 & 146 & 261 \\
5 & długoterminowe rozliczenia międzyokresowe & 899 & 874 & 923 & 934 & 991 & 929 \\
6 & aktywa przeznaczone do sprzedaży & - & - & 139 & - & - & - \\
II & aktywa obrotowe & 5128 & 2193 & 1938 & 2078 & 2330 & 2418 \\
1 & zapasy & 214 & 194 & 200 & 198 & 228 & 163 \\
2 & należności krótkoterminowe & 1506 & 1408 & 1199 & 1372 & 1591 & 1827 \\
3 & inwestycje krótkoterminowe & 3330 & 524 & 365 & 437 & 426 & 348 \\
4 & krótkoterminowe rozliczenia międzyokresowe & 78 & 67 & 88 & 71 & 84 & 80 \\
5 & aktywa przeznaczone do sprzedaży & - & - & 86 & - & - & - \\
\hline aktywa razem & 28219 & 24138 & 22802 & 22104 & 21652 & 22588 \\
\hline
\end{tabular}

Źródło: Opracowanie własne na podstawie Orange Polska (2012a-2017a).

Tabela 2 .

Dynamika aktywów Grupy Orange w latach 2011-2016 (w \%)

\begin{tabular}{llrrrrr}
\hline \multicolumn{1}{c}{ Lp. Aktywa } & \multicolumn{1}{c}{ 2011/2012 } & $2012 / 2013$ & $2013 / 2014$ & $2014 / 2015$ & $2015 / 2016$ \\
\hline I & aktywa trwałe & 95,0 & 94,3 & 96,6 & 96,5 & 104,4 \\
2 & wartości niematerialne i prawne & 100 & 100,5 & 101,9 & 97,1 & 113,2 \\
2 & rzeczowe aktywa trwałe & 93,4 & 91,5 & 91,6 & 96,5 & 96,9 \\
3 & należności długoterminowe & - & - & - & 152,2 & 206,2 \\
4 & inwestycje długoterminowe & 48,1 & 9,0 & 646,2 & 173,8 & 178,8 \\
5 & długoterminowe rozliczenia międzyokresowe & 97,2 & 105,1 & 100,6 & 106,1 & 93,7 \\
6 & aktywa przeznaczone do sprzedaży & - & - & - & - & - \\
II & aktywa obrotowe & 42,8 & 83,8 & 112,2 & 112,1 & 103,8 \\
1 & zapasy & 90,6 & 103,1 & 99,0 & 115,5 & 71,5 \\
2. & należności krótkoterminowe & 93,3 & 84,8 & 114,4 & 116,0 & 114,8 \\
3 & inwestycje krótkoterminowe & 16,7 & 60,5 & 94,0 & 97,7 & 81,7 \\
4 & krótkoterminowe rozliczenia międzyokresowe & 85,9 & 131,3 & 80,7 & 118,3 & 95,2 \\
5 & aktywa przeznaczone do sprzedaży & - & - & - & - & - \\
\hline aktywa razem & 85,5 & 94,4 & 96,9 & 98,0 & 104,3 \\
\hline
\end{tabular}

Źródło: Opracowanie własne na podstawie Orange Polska (2012a-2017a). 
Tabela 3.

Struktura aktywów Grupy Orange w latach 2011-2016 (w \%)

\begin{tabular}{|c|c|c|c|c|c|c|c|}
\hline Lp. & Aktywa & 2011 & 2012 & 2013 & 2014 & 2015 & 2016 \\
\hline I & aktywa trwale & 81,8 & 90,9 & 91,5 & 90,6 & 89,2 & 89,3 \\
\hline 1 & wartości niematerialne i prawne & 24,7 & 28,9 & 30,8 & 32,4 & 32,1 & 34,8 \\
\hline 2 & rzeczowe aktywa trwałe & 52,8 & 57,7 & 56 & 53 & 50,9 & 47,3 \\
\hline 3 & należności długoterminowe & - & - & - & 0,6 & 1 & 1,9 \\
\hline 4 & inwestycje długoterminowe & 1,1 & 0,6 & 0,1 & 0,4 & 0,6 & 1,2 \\
\hline 5 & długoterminowe rozliczenia międzyokresowe & 3,2 & 3,6 & 4 & 4,2 & 4,6 & 4,1 \\
\hline 6 & aktywa przeznaczone do sprzedaży & - & - & 0,6 & - & - & - \\
\hline II & aktywa obrotowe & 18,2 & 9,1 & 8,5 & 9,4 & 10,8 & 10,7 \\
\hline 1 & zapasy & 0,8 & 0,9 & 0,9 & 0,9 & 1,1 & 0,7 \\
\hline 2 & należności krótkoterminowe & 5,3 & 5,8 & 5,3 & 6,2 & 7,3 & 8,1 \\
\hline 3 & inwestycje krótkoterminowe & 11,0 & 0,8 & 1,1 & 2,0 & 2,0 & 1,5 \\
\hline 4 & krótkoterminowe rozliczenia międzyokresowe & 0,3 & 1,6 & 0,8 & 0,3 & 0,4 & 0,4 \\
\hline 5 & aktywa przeznaczone do sprzedaży & - & - & 0,4 & - & - & - \\
\hline akty & wa razem & 100,0 & 100,0 & 100,0 & 100,0 & 100,0 & 100,0 \\
\hline
\end{tabular}

Źródło: Opracowanie własne na podstawie Orange Polska (2012a-2017a).

Tabela 4.

Wartość pasywów Grupy Orange w latach 2011-2016 (w mln PLN)

\begin{tabular}{|c|c|c|c|c|c|c|c|}
\hline Lp. & Pasywa & 2011 & 2012 & 2013 & 2014 & 2015 & 2016 \\
\hline I & kapitał własny & 14334 & 12958 & 12631 & 12398 & 11977 & 10009 \\
\hline 1 & kapital podstawowy & 4007 & 4007 & 3937 & 3937 & 3937 & 3937 \\
\hline 2 & kapitał zapasowy & 832 & 832 & 832 & 832 & 832 & 832 \\
\hline 3 & akcje własne & $(200)$ & $(400)$ & - & - & - & - \\
\hline 4 & $\begin{array}{l}\text { różnice kursowe z przeliczenia spółek } \\
\text { zależnych }\end{array}$ & (5) & (5) & - & - & - & - \\
\hline 5 & pozostałe kapitały rezerwowe & 24 & $(37)$ & $(7)$ & (119) & $(103)$ & (29) \\
\hline 6 & zyski zatrzymane & 9673 & 8559 & 7867 & 7746 & 7309 & 5267 \\
\hline 7 & udziały nie dajce kontroli & 3 & 2 & 2 & 2 & 2 & 2 \\
\hline II & zobowiązania i rezerwy na zobowiązania & 13885 & 11180 & 10171 & 9706 & 9675 & 12579 \\
\hline 1 & rezerwy na zobowiązania & 3386 & 1216 & 1212 & 1093 & 1161 & 1130 \\
\hline 2 & zobowiązania długoterminowe & 5461 & 4413 & 2462 & 4647 & 4073 & 8070 \\
\hline 3 & zobowiązania krótkoterminowe & 4445 & 5009 & 6007 & 3517 & 3896 & 2818 \\
\hline 4 & rozliczenia międzyokresowe & 593 & 542 & 452 & 449 & 545 & 561 \\
\hline 5 & $\begin{array}{l}\text { zobowiązania powiązane z aktywami } \\
\text { przeznaczonymi do sprzedaży }\end{array}$ & - & - & 38 & - & - & - \\
\hline \multicolumn{2}{|c|}{ pasywa razem } & 28219 & 24138 & 22802 & 22104 & 21652 & 22588 \\
\hline
\end{tabular}

Uwagi:

Kwoty w nawiasach oznaczają wartości ujemne.

Źródło: Opracowanie własne na podstawie Orange Polska (2012a-2017a). 
Tabela 5.

Dynamika pasywów Grupy Orange w latach 2011-2016 (w \%)

\begin{tabular}{|c|c|c|c|c|c|c|}
\hline Lp. & Pasywa & $2011 / 2012$ & $2012 / 2013$ & $2013 / 2014$ & $2014 / 2015$ & $2015 / 2016$ \\
\hline I & kapitał własny & 90,4 & 98,3 & 98,2 & 96,6 & 83,6 \\
\hline 1 & kapitał podstawowy & 100,0 & 100,0 & 100,0 & 100,0 & 100,0 \\
\hline 2 & kapitał zapasowy & 100,0 & 3,4 & 100,0 & 100,0 & 100,0 \\
\hline 3 & akcje własne & 200,0 & - & - & - & - \\
\hline 4 & kapitał z aktualizacji wyceny & - & - & - & - & - \\
\hline 5 & pozostałe kapitały rezerwowe & 154,2 & 18,9 & 1700,0 & 86,6 & 28,2 \\
\hline 6 & zysk zatrzymany & 88,5 & 91,9 & 98,2 & 94,4 & 72,1 \\
\hline 7. & udziały niedające kontroli & 66,7 & 100,0 & 100,0 & 100,0 & 100,0 \\
\hline II & zobowiązania i rezerwy na zobowiązania & 80,5 & 83,0 & 95,8 & 99,7 & 130,0 \\
\hline 1 & rezerwy na zobowiązania & 35,4 & 99,7 & 90,2 & 106,2 & 97,3 \\
\hline 2 & zobowiązania długoterminowe & 81,5 & 55,8 & 188,7 & 87,6 & 198,1 \\
\hline 3 & zobowiązania krótkoterminowe & 112,7 & 119,4 & 58,5 & 110,8 & 72,3 \\
\hline 4 & rozliczenia międzyokresowe & 91,4 & 83,3 & 94,1 & 121,4 & 102,9 \\
\hline pasy & wa razem & 85,5 & 94,4 & 96,9 & 98,0 & 104,3 \\
\hline
\end{tabular}

Źródło: Opracowanie własne na podstawie Orange Polska (2012a-2017a).

Tabela 6 .

Struktura pasywów Grupy Orange w latach 2011-2016 (w\%)

\begin{tabular}{|c|c|c|c|c|c|c|c|}
\hline Lp. & Pasywa & 2011 & 2012 & 2013 & 2014 & 2015 & 2016 \\
\hline I & kapitał własny & 50,8 & 53,7 & 55,4 & 56,1 & 55,3 & 44,3 \\
\hline 1 & kapital podstawowy & 14,2 & 16,3 & 17,3 & 17,8 & 18,2 & 17,4 \\
\hline 2 & kapitał zapasowy & 2,9 & 3,4 & 3,6 & 3,8 & 3,8 & 3,7 \\
\hline 3 & akcje własne & $-0,7$ & $-1,7$ & - & - & - & - \\
\hline 4 & $\begin{array}{l}\text { różnice kursowe z przeliczenia spółek } \\
\text { zależnych }\end{array}$ & - & - & - & - & - & - \\
\hline 5 & kapitał z aktualizacji wyceny & - & - & - & - & - & - \\
\hline 6 & pozostałe kapitały rezerwowe & 0,1 & 0,1 & - & $-0,5$ & $-0,5$ & $-0,13$ \\
\hline 7 & zysk zatrzymany & 34,3 & 35,6 & 34,5 & 35,0 & 33,8 & 23,32 \\
\hline 8 & $\begin{array}{l}\text { kapitał własny przypisany udziałom } \\
\text { niedającym kontroli }\end{array}$ & - & - & - & - & - & - \\
\hline B. & zobowiązania i rezerwy na zobowiązania & 49,2 & 46,3 & 44,6 & 43,9 & 44,7 & 55,7 \\
\hline 1 & rezerwy na zobowiązania & 12,2 & 5,0 & 5,3 & 4,9 & 5,4 & 5,00 \\
\hline 2 & zobowiązania długoterminowe & 19,2 & 18,3 & 10,8 & 21,0 & 18,8 & 35,7 \\
\hline 3 & zobowiązania krótkoterminowe & 15,7 & 20,8 & 26,3 & 16,0 & 18,0 & 12,4 \\
\hline 4 & rozliczenia międzyokresowe & 2,1 & 2,2 & 2,0 & 2,0 & 2,5 & 2,48 \\
\hline 5 & $\begin{array}{l}\text { zobowiązania powiązane z aktywami } \\
\text { przeznaczonymi do sprzedaży }\end{array}$ & - & - & 0,2 & - & - & 55,6 \\
\hline \multicolumn{2}{|c|}{ pasywa razem } & 100,0 & 100,0 & 100,0 & 100,0 & 100,0 & 100,0 \\
\hline
\end{tabular}

Źródło: Opracowanie własne na podstawie Orange Polska (2012a-2017a). 
Tabela 7.

Rachunek zysków i strat Grupy Orange w latach 2011-2016 (w mln PLN)

\begin{tabular}{|c|c|c|c|c|c|c|c|}
\hline Lp. & Dane finansowe & 2011 & 2012 & 2013 & 2014 & 2015 & 2016 \\
\hline I. & przychody ze sprzedaży & 14922 & 14147 & 12923 & 12212 & 11840 & 11538 \\
\hline II. & koszty działalności podstawowej & $(9043)$ & (8986) & $(8386)$ & $(7987)$ & $(7984)$ & (8378) \\
\hline 1. & ustugi obce & $(7012)$ & (6953) & $(6440)$ & $(6113)$ & $(6271)$ & (6432) \\
\hline 2. & koszty świadczeń pracowniczych & $(2031)$ & (2033) & $(1946)$ & $(1874)$ & $(1713)$ & (1946) \\
\hline III. & zysk/(strata) ze sprzedaży & 5879 & 5161 & 4537 & 4225 & 3856 & 3160 \\
\hline IV. & pozostate przychody operacyjne & 1623 & 511 & 360 & 569 & 329 & 280 \\
\hline 1. & zyski ze sprzedaży aktywów & 32 & 35 & 40 & 57 & 71 & 70 \\
\hline 2. & zyski ze sprzedaży TP Emitel & 1183 & - & - & - & - & - \\
\hline 3. & zysk ze sprzedaży Wirtualnej Polski SA & - & - & - & 191 & - & - \\
\hline 4. & $\begin{array}{l}\text { udział w zyskach inwestycji wycenianych metoda } \\
\text { praw własności }\end{array}$ & 1 & 5 & - & - & - & - \\
\hline 5. & pozostałe przychody & 407 & 479 & 320 & 313 & 246 & 210 \\
\hline V. & pozostałe koszty operacyjne & $(5285)$ & $(4099)$ & $(4$ 109) & $(3808)$ & $(3613)$ & $(5105)$ \\
\hline 1. & $\begin{array}{l}\text { obciążenia podatkowe inne niż podatek } \\
\text { dochodowy }\end{array}$ & $(340)$ & (308) & $(323)$ & (329) & $(301)$ & (304) \\
\hline 2. & $\begin{array}{l}\text { utrata wartości oraz koszt sprzedanych należności } \\
\text { handlowych i pozostalych }\end{array}$ & (259) & (209) & (221) & $(172)$ & (98) & (89) \\
\hline 3. & straty z tytułu różnic kursowych netto & (71) & (12) & - & - & - & - \\
\hline 4. & opłata licencyjna za używanie marki Orange & $(125)$ & $(140)$ & $(164)$ & (134) & $(134)$ & (127) \\
\hline 5. & pozostałe koszty i zmiany stanu rezerw netto & $(571)$ & (169) & (99) & (83) & $(80)$ & (67) \\
\hline 6. & koszty restrukturyzacji & $(172)$ & - & - & - & - & - \\
\hline 7. & spór z DPTG & (35) & - & - & - & - & - \\
\hline 8. & amortyzacja & $(3703)$ & $(3261)$ & (3 107) & $(3073)$ & $(2871)$ & $(2725)$ \\
\hline 9. & $\begin{array}{l}\text { (utworzenie)/odwrócenie odpisu z tytułu utraty } \\
\text { wartości aktywów trwalych }\end{array}$ & (9) & (16) & (9) & $(17)$ & (12) & $(1792)$ \\
\hline 10. & koszt rozwiązania stosunków pracy & - & 8 & (186) & 8 & (129) & - \\
\hline VI. & zysk/(strata) operacyjny & 2217 & 1573 & 788 & 986 & 572 & $(1354)$ \\
\hline VII. & przychody finansowe & 118 & 55 & 14 & 12 & 17 & 22 \\
\hline 1. & przychody odsetkowe & 111 & 27 & 12 & 14 & 17 & 22 \\
\hline 2. & zyski z tytułu różnic kursowych & 7 & 28 & 2 & 2 & - & - \\
\hline VIII. & koszty finansowe & $(550)$ & $(612)$ & $(488)$ & $(417)$ & (308) & $(381)$ \\
\hline 1. & koszty odsetkowe i pozostałe koszty finansowe & $(450)$ & $(517)$ & (388) & (303) & (216) & (282) \\
\hline 2. & koszty dyskonta & $(100)$ & (95) & $(100)$ & (114) & (92) & (99) \\
\hline IX. & zysk/(strata) z działalności gospodarczej & 1785 & 1016 & 310 & 581 & 281 & $(1713)$ \\
\hline 1. & wyniki zdarzeń nadzwyczajnych & - & - & - & - & - & - \\
\hline $\mathrm{X}$ & zysk/(strata) brutto & 1785 & 1016 & 310 & 581 & 281 & $(1713)$ \\
\hline XI. & podatek dochodowy & 133 & $(161)$ & (16) & $(46)$ & (27) & (33) \\
\hline XII. & skonsolidowany zysk/(strata) netto & 1918 & 855 & 294 & 535 & 254 & $(1746)$ \\
\hline
\end{tabular}

Uwagi:

Kwoty w nawiasach oznaczają wartości ujemne.

Źródło: Opracowanie własne na podstawie Orange Polska (2012a-2017a). 
Tabela 8.

Dynamika wyniku finansowego Orange Polska w latach 2011-2016 (w \%)

\begin{tabular}{|c|c|c|c|c|c|c|}
\hline Lp. & Dane finansowe & $2011 / 2012$ & $2012 / 2013$ & $2013 / 2014$ & $2014 / 2015$ & $2015 / 2016$ \\
\hline I. & przychody ze sprzedaży & 94,8 & 91,3 & 94,4 & 96,9 & 97,5 \\
\hline II. & koszty działalności podstawowej & 107,3 & 93,3 & 95,2 & 99,9 & 104,9 \\
\hline 1. & ustugi obce & 99,2 & 92,6 & 94,9 & 102,6 & 102,6 \\
\hline 2. & koszty świadczeń pracowniczych & 148,8 & 95,7 & 96,3 & 91,4 & 113,6 \\
\hline III. & zysk ze sprzedaży & 78,9 & 87,9 & 97,5 & 87,1 & 82,0 \\
\hline IV. & pozostałe przychody operacyjne & 31,5 & 70,4 & 158,1 & 57,8 & 85,1 \\
\hline 1. & zyski ze sprzedaży aktywów & 109,4 & 114,3 & 142,5 & 124,6 & 98,6 \\
\hline 2. & zyski ze sprzedaży TP Emitel & - & - & - & - & - \\
\hline 3. & zysk ze sprzedaży Wirtualnej Polski SA & - & - & - & - & - \\
\hline 4. & $\begin{array}{l}\text { udział w zyskach inwestycji } \\
\text { wycenianych metodą praw własności }\end{array}$ & 500,0 & - & - & - & - \\
\hline 5. & pozostałe przychody & 117,7 & 66,8 & 97,8 & 78,6 & 85,4 \\
\hline $\mathrm{V}$ & pozostałe koszty operacyjne & 77,7 & 100,1 & 92,7 & 95,0 & 141,3 \\
\hline 1. & $\begin{array}{l}\text { obciążenia podatkowe inne niż podatek } \\
\text { dochodowy }\end{array}$ & 90,6 & 104,9 & 101,9 & 91,5 & 101,0 \\
\hline 2. & $\begin{array}{l}\text { utrata wartości oraz koszt sprzedanych } \\
\text { należności handlowych i pozostałych }\end{array}$ & 80,7 & 105,7 & 77,8 & 57,0 & 90,8 \\
\hline 3. & straty z tytułu różnic kursowych netto & 16,9 & - & - & - & - \\
\hline 4. & $\begin{array}{l}\text { opłata licencyjna za używanie marki } \\
\text { Orange }\end{array}$ & 112,0 & 117,1 & 81,7 & 100 & 94,8 \\
\hline 5. & $\begin{array}{l}\text { pozostałe koszty i zmiany stanu rezerw } \\
\text { netto }\end{array}$ & 29,6 & 58,6 & 83,8 & 96,4 & 83,8 \\
\hline 6. & koszty restrukturyzacji & - & - & - & - & - \\
\hline 7. & spór z DPTG & - & - & - & - & - \\
\hline 8. & amortyzacja & 88,1 & 95,3 & 98,9 & 93,4 & 94,9 \\
\hline 9. & $\begin{array}{l}\text { (utworzenie)/odwrócenie odpisu z tytu- } \\
\text { łu utraty wartości aktywów trwałych }\end{array}$ & 177,8 & 56,3 & 188,9 & 70,6 & 14933,3 \\
\hline 10. & koszty rozwiązania stosunków pracy & - & -2325 & $-4,3$ & $-1612,5$ & - \\
\hline VI. & zysk operacyjny & 70,9 & 50,1 & 125,1 & 58,0 & $-236,7$ \\
\hline VII. & przychody finansowe & 46,6 & 25,4 & 85,7 & 141,7 & 129,4 \\
\hline 1. & przychody odsetkowe & 24,3 & 44,4 & 116,7 & 121,4 & 129,4 \\
\hline 2. & zyski z tytułu różnic kursowych & 400,0 & 7,0 & $-100,0$ & - & - \\
\hline VIII. & koszty finansowe & 111,3 & 85,8 & 85,4 & 73,9 & 123,7 \\
\hline 1. & $\begin{array}{l}\text { koszty odsetkowe i pozostałe koszty } \\
\text { finansowe }\end{array}$ & 114,9 & 79,7 & 78,1 & 71,3 & 13,0 \\
\hline 2. & koszty dyskonta & 95,0 & 105,3 & 114 & 80,7 & $0,6107,6$ \\
\hline IX. & zysk z działalności gospodarczej & 56,9 & 30,5 & 187,4 & 48,4 & $-609,6$ \\
\hline 1. & wynik zdarzeń nadzwyczajnych & - & - & - & - & - \\
\hline $\mathrm{X}$ & zysk z działalności brutto & 56,9 & 30,5 & 187,4 & 48,4 & $-609,6$ \\
\hline $\mathrm{XI}$. & podatek dochodowy & -121 & 0,1 & 287,5 & 58,7 & 122,2 \\
\hline XII. & skonsolidowany zysk netto & 44,6 & 34,4 & 182 & 47,4 & $-687,4$ \\
\hline
\end{tabular}

Źródło: Opracowanie własne na podstawie Orange Polska (2012a-2017a). 
Tabela 9.

Wskaźniki płynności Grupy Orange w latach 2011-2016

\begin{tabular}{ccccccc}
\hline Wskaźniki & 2011 & 2012 & 2013 & 2014 & 2015 & 2016 \\
\hline wskaźnik płynności bieżącej & 0,63 & 0,34 & 0,25 & 0,44 & 0,45 & 0,58 \\
wskaźnik płynności szybkiej & 0,60 & 0,30 & 0,23 & 0,38 & 0,39 & 0,52 \\
wskaźnik ogólnej płynności & 0,41 & 0,08 & 0,05 & 0,09 & 0,08 & 0,08 \\
\hline
\end{tabular}

Źródło: Opracowanie własne na podstawie Orange Polska (2012a-2017a).

Tabela 10.

Wskaźniki zadłużenia Grupy Orange w latach 2011-2016

\begin{tabular}{lcccccc}
\hline \multicolumn{1}{c}{ Wskaźniki } & 2011 & 2012 & 2013 & 2014 & 2015 & 2016 \\
\hline wskaźnik ogólnego zadłużenia & 0,49 & 0,48 & 0,44 & 0,44 & 0,45 & 0,56 \\
wskaźnik zadłużenia kapitału własnego & 0,97 & 0,86 & 0,80 & 0,78 & 0,81 & 1,26 \\
wskaźnik zadłużenia krótkoterminowego & 0,29 & 0,27 & 0,32 & 0,21 & 0,24 & 0,18 \\
wskaźnik zadłużenia długoterminowego & 0,40 & 0,36 & 0,22 & 0,40 & 0,37 & 0,84 \\
\hline
\end{tabular}

Źródło: Opracowanie własne na podstawie Orange Polska (2012a-2017a).

Tabela 11.

Wskaźniki rentowności Grupy Orange w latach 2011-2016

\begin{tabular}{lrrrrrr}
\hline \multicolumn{1}{c}{ Wskaźniki } & 2011 & 2012 & 2013 & 2014 & 2015 & 2016 \\
\hline wskaźnik ROA & 0,07 & 0,02 & 0,02 & 0,02 & 0,01 & $-0,08$ \\
wskaźnik rentowności sprzedaży netto & 0,13 & 0,04 & 0,04 & 0,04 & 0,02 & $-0,15$ \\
wskaźnik ROE & 0,13 & 0,04 & 0,04 & 0,04 & 0,02 & $-0,17$ \\
\hline
\end{tabular}

Uwagi:

Wskaźnik ROA (return on assets) - wskaźnik rentowności aktywów, wskaźnik ROE (return on equity) - wskaźnik rentowności kapitału własnego.

Źródło: Opracowanie własne na podstawie Orange Polska (2012a-2017a).

Tabela 12.

Zobowiązania z tytułu świadczeń pracowniczych Grupy Orange w latach 2011-2016 (w mln PLN)

\begin{tabular}{lrrrrrr}
\hline \multicolumn{1}{c}{ Elementy świadczeń pracowniczych } & 2011 & 2012 & 2013 & 2014 & 2015 & 2016 \\
\hline $\begin{array}{l}\text { nagrody jubileuszowe } \\
\text { odprawy emerytalno-rentowe oraz pozostałe świadczenia po okresie }\end{array}$ & 125 & 152 & 122 & 145 & 131 & 104 \\
$\begin{array}{l}\text { zatrudnienia } \\
\text { wynagrodzenia i pozostałe zobowiązania z tytułu świadczeń }\end{array}$ & 247 & 197 & 221 & 118 & 52 \\
$\begin{array}{l}\text { pracowniczych } \\
\text { Razem }\end{array}$ & 525 & 579 & 483 & 524 & 439 & 332 \\
\hline
\end{tabular}

Źródło: Opracowanie własne na podstawie Orange Polska (2012a-2017a). 
Tabela 13.

Przychody ze sprzedaży usług Grupy Orange w latach 2011-2016 (w mln PLN)

\begin{tabular}{lrrrrrr}
\hline \multicolumn{1}{c}{ Przychody } & 2011 & 2012 & 2013 & 2014 & 2015 & 2016 \\
\hline usługi komórkowe & 7006 & 6988 & 6259 & 6140 & 6141 & 6421 \\
usługi detaliczne & 5650 & 5624 & 5339 & 4967 & 4589 & 4296 \\
usługi hurtowe (w tym rozliczenia z innymi operatorami) & 1236 & 1223 & 771 & 746 & 909 & 1037 \\
$\begin{array}{l}\text { sprzedaż sprzętu do usług komórkowych } \\
\text { usługi stacjonarne }\end{array}$ & 120 & 141 & 149 & 427 & 643 & 1088 \\
$\begin{array}{l}\text { usługi wąskopasmowe } \\
\text { usługi szerokopasmowe, telewizja i transmisja głosu przez }\end{array}$ & 7192 & 6593 & 6057 & 5520 & 5083 & 4662 \\
Internet & 3334 & 2747 & 2297 & 1983 & 1746 & 1527 \\
rozwiązania teleinformatyczne dla przedsiębiorstw oraz & 1510 & 1586 & 1687 & 1663 & 1601 & 1490 \\
z zakresu infrastruktury sieciowej & 1209 & 1093 & 1020 & 933 & 916 & 892 \\
usługi hurtowe (w tym rozliczenia z innymi operatorami) & 1139 & 1167 & 1053 & 941 & 820 & 753 \\
pozostałe przychody & 600 & 560 & 607 & 552 & 616 & 455 \\
\hline przychody razem & 14922 & 14141 & 12923 & 12212 & 11840 & 11538 \\
\hline
\end{tabular}

Źródło: Opracowanie własne na podstawie Orange Polska (2012a-2017a).

Tabela 14.

Dynamika przychodów ze sprzedaży usług Grupy Orange w latach 2011-2016 (w \%)

\begin{tabular}{|c|c|c|c|c|c|}
\hline Przychody & $2011 / 2012$ & $2012 / 2013$ & $2013 / 2014$ & $2014 / 2015$ & $2015 / 2016$ \\
\hline usługi komórkowe & 99,7 & 89,6 & 98,1 & 100,0 & 104,6 \\
\hline usługi detaliczne & 99,5 & 94,9 & 93,0 & 92,4 & 93,6 \\
\hline $\begin{array}{l}\text { ustugi hurtowe (w tym rozliczenia z innymi } \\
\text { operatorami) }\end{array}$ & 98,9 & 63,0 & 96,8 & 121,8 & 114,1 \\
\hline sprzedaż sprzętu do ustug komórkowych & 117,5 & 105,7 & 286,6 & 150,6 & 169,2 \\
\hline ustugi stacjonarne & 91,7 & 91,9 & 91,1 & 92,1 & 91,7 \\
\hline usługi wąskopasmowe & 82,4 & 83,6 & 86,3 & 88,0 & 87,5 \\
\hline $\begin{array}{l}\text { ustugi szerokopasmowe, telewizja i transmisja głosu } \\
\text { przez Internet }\end{array}$ & 105,0 & 106,4 & 98,6 & 96,3 & 93,1 \\
\hline $\begin{array}{l}\text { rozwiązania teleinformatyczne dla przedsiębiorstw } \\
\text { oraz z zakresu infrastruktury sieciowej }\end{array}$ & 90,4 & 93,3 & 91,5 & 98,2 & 97,4 \\
\hline $\begin{array}{l}\text { ustugi hurtowe (w tym rozliczenia z innymi } \\
\text { operatorami) }\end{array}$ & 102,5 & 90,2 & 89,4 & 87,1 & 91,8 \\
\hline pozostałe przychody & 93,3 & 108,4 & 90,9 & 111,6 & 73,9 \\
\hline przychody razem & 94,8 & 91,4 & 94,5 & 97,0 & 97,4 \\
\hline
\end{tabular}

Źródło: Opracowanie własne na podstawie Orange Polska (2012a-2017a). 
Tabela 15.

Struktura przychodów ze sprzedaż usług Grupy Orange w latach 2011-2016 (w \%)

\begin{tabular}{|c|c|c|c|c|c|c|}
\hline Przychody & 2011 & 2012 & 2013 & 2014 & 2015 & 2016 \\
\hline ustugi komórkowe & 47,0 & 49,4 & 48,4 & 50,3 & 51,9 & 55,7 \\
\hline ustugi detaliczne & 37,9 & 39,8 & 41,3 & 40,7 & 38,8 & 37,2 \\
\hline ustugi hurtowe (w tym rozliczenia z innymi operatorami) & 8,3 & 8,6 & 6,0 & 6,1 & 7,7 & 9,0 \\
\hline sprzedaż sprzętu do ustug komórkowych & 0,8 & 1,0 & 1,2 & 3,5 & 5,4 & 9,4 \\
\hline ustugi stacjonarne & 48,2 & 46,6 & 46,9 & 45,2 & 42,9 & 40,4 \\
\hline usługi wąskopasmowe & 22,3 & 19,4 & 17,8 & 16,2 & 14,7 & 13,2 \\
\hline $\begin{array}{l}\text { usługi szerokopasmowe, telewizja i transmisja głosu przez } \\
\text { Internet }\end{array}$ & 10,1 & 11,2 & 13,1 & 13,6 & 13,5 & 12,9 \\
\hline $\begin{array}{l}\text { rozwiązania teleinformatyczne dla przedsiębiorstw oraz } \\
\text { z zakresu infrastruktury sieciowej }\end{array}$ & 8,1 & 7,7 & 7,9 & 7,6 & 7,7 & 7,7 \\
\hline ustugi hurtowe (w tym rozliczenia $z$ innymi operatorami) & 7,6 & 8,3 & 8,1 & 7,7 & 6,9 & 6,5 \\
\hline pozostałe przychody & 4,0 & 4,0 & 4,7 & 4,5 & 5,2 & 3,9 \\
\hline przychody razem & 100,0 & 100,0 & 100,0 & 100,0 & 100,0 & 100,0 \\
\hline
\end{tabular}

Źródło: Opracowanie własne na podstawie Orange Polska (2012a-2017a).

Wykres 1.

Zatrudnienie w Grupie Orange w latach 2011-2016

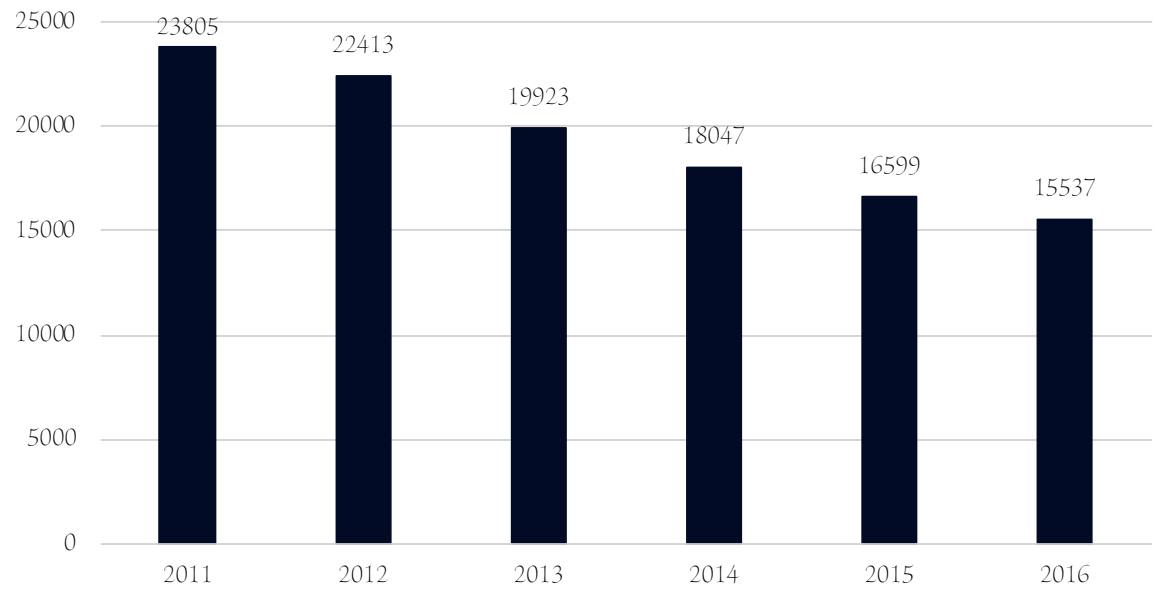

Źródło: Opracowanie własne na podstawie Orange Polska (2012a-2017a). 
Wykres 2.

Dynamika zatrudnienia Grupy Orange w latach 2011-2016 (w \%)

96

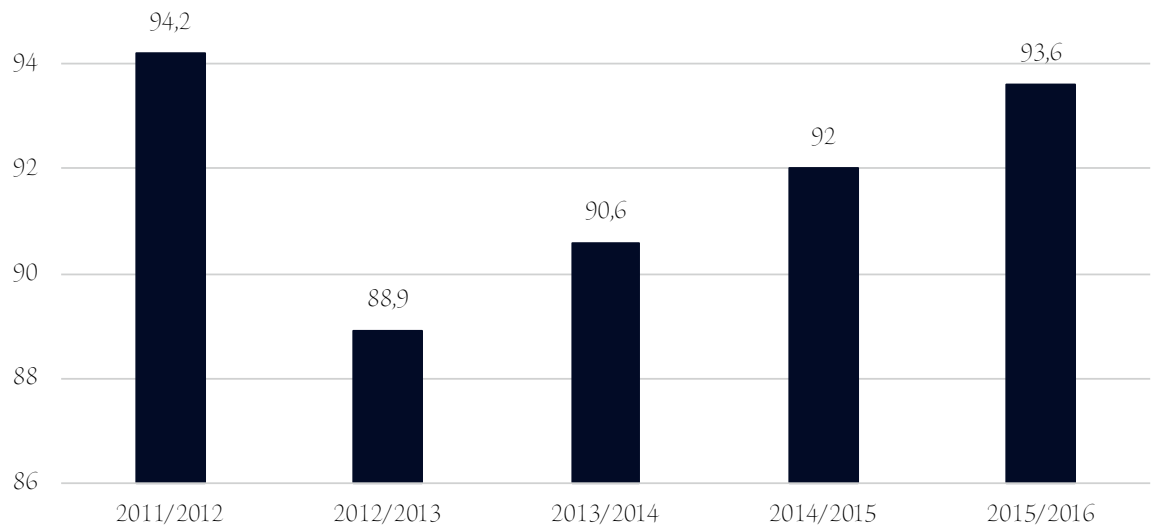

Żródło: Opracowanie własne na podstawie Orange Polska (2012a-2017a).

Wykres 3.

Dynamika zobowiązań z tytułu świadczeń pracowniczych Grupy Orange w latach 2011-2016 (w \%)

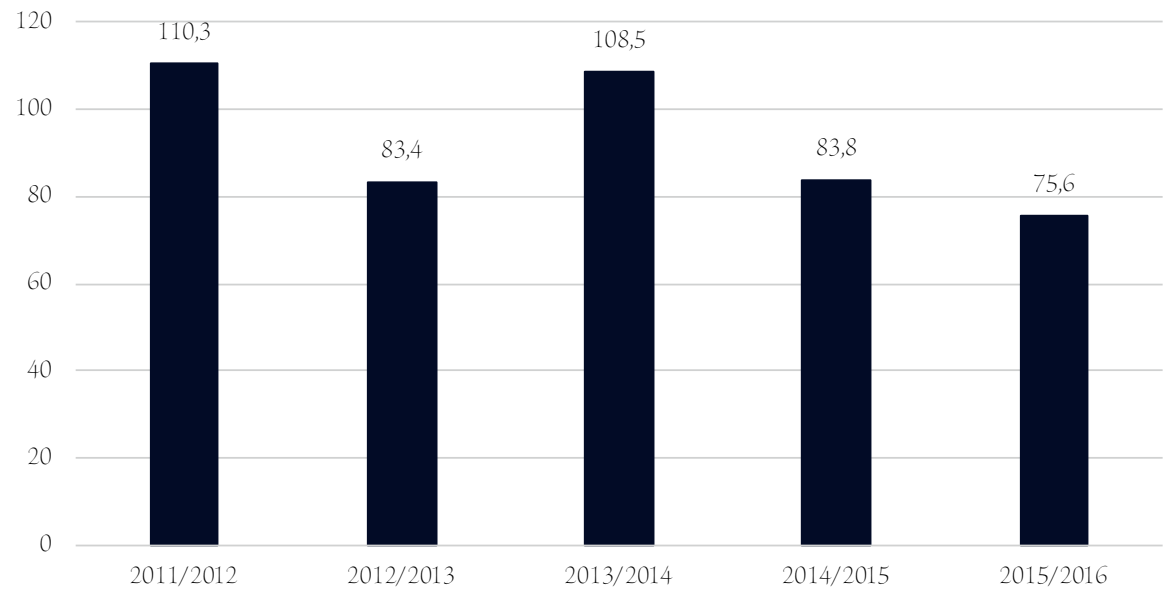

Źródło: Opracowanie własne na podstawie Orange Polska (2012a-2017a). 
Wykres 4.

Indywidualna wydajność pracy pracownika Grupy Orange w latach 2011-2016 (w PLN)

760000

720000

713296

680000

676678

648647

640000
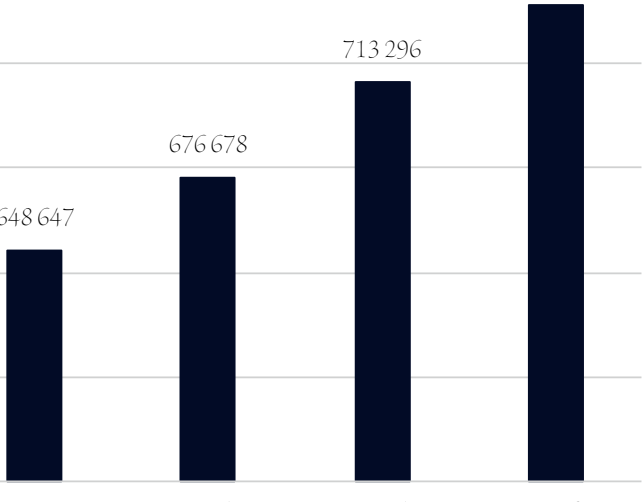

560000

2011

2012

2013

2014

2015

2016

Źródło: Opracowanie własne na podstawie Orange Polska (2012a-2017a).

Wykres 5.

Dynamika indywidualnej wydajność pracy pracownika Grupy Orange w latach 2011-2016 (w \%)

106

105,4

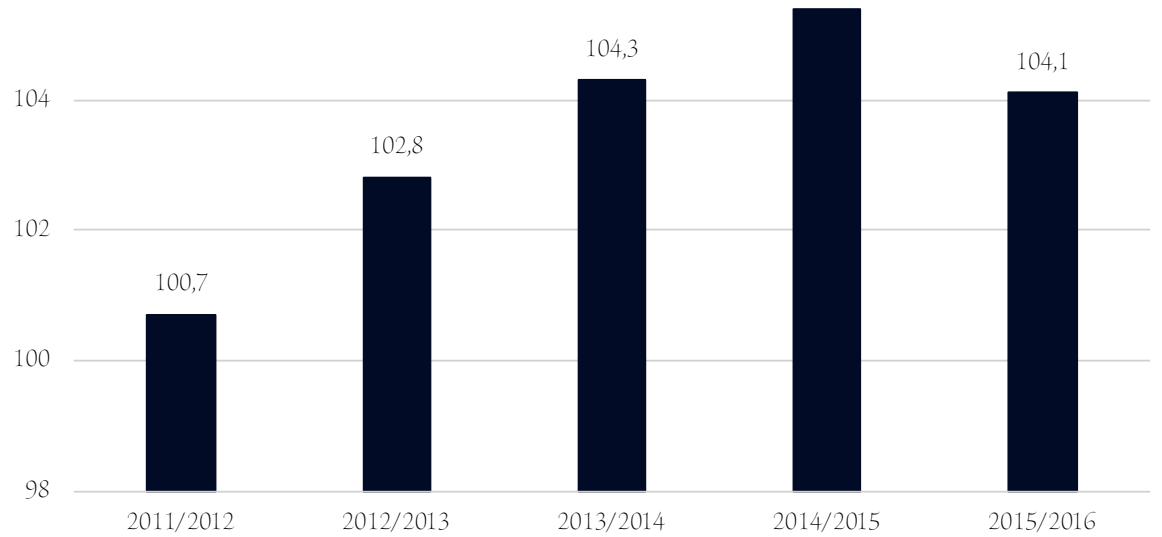

Źródło: Opracowanie własne na podstawie Orange Polska (2012a-2017a). 
Wykres 6.

Wydatki na wynagrodzenia pracowników Grupy Orange w latach 2011-2016 (w mln PLN)

1900

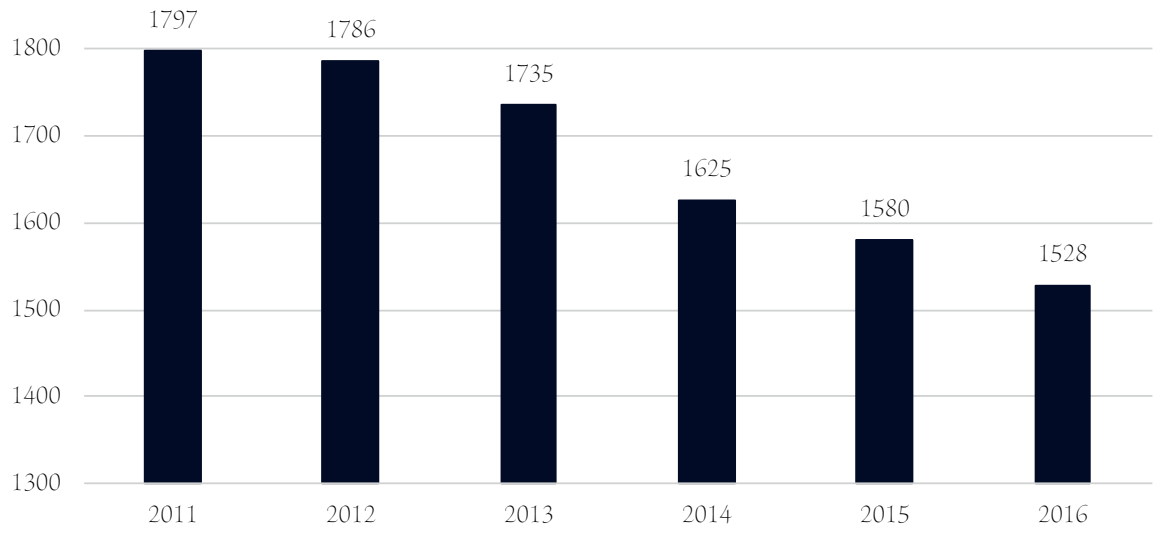

Źródło: Opracowanie własne na podstawie Orange Polska (2012a-2017a).

Wykres 7.

Średnie roczne wynagrodzenie per capita Grupy Orange w latach 2011-2016 (w PLN)

120000

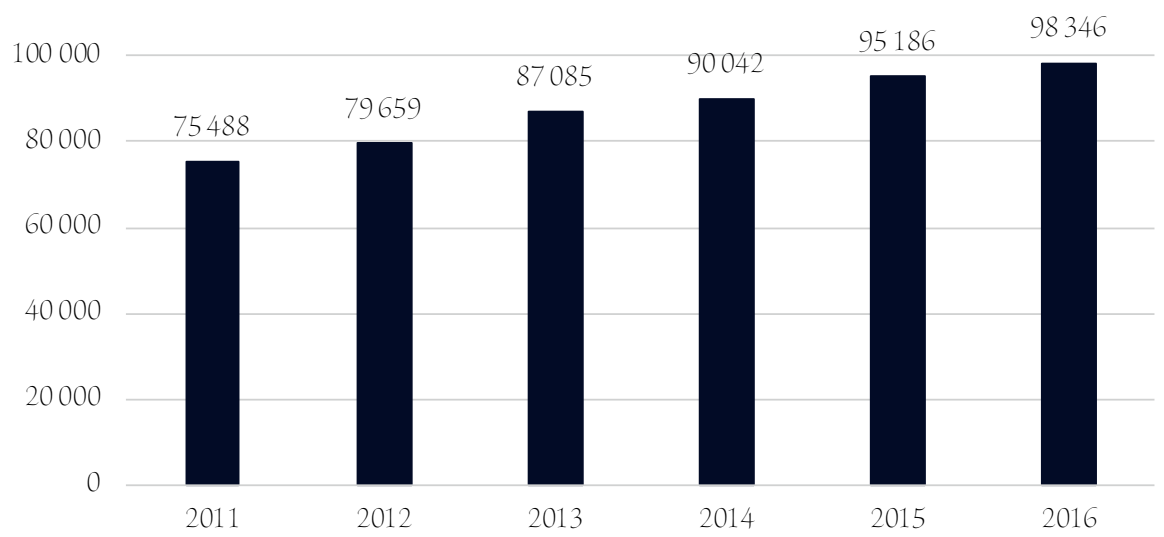

Żródło: Opracowanie własne na podstawie Orange Polska (2012a-2017a). 


\title{
Wykres 8.
}

Dynamika średniego rocznego wynagrodzenia per capita Grupy Orange w latach 2011-2016 (w \%)

106

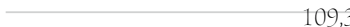

104

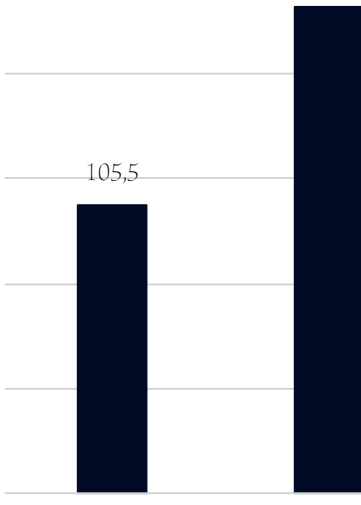

$2011 / 2012$

$2012 / 2013$

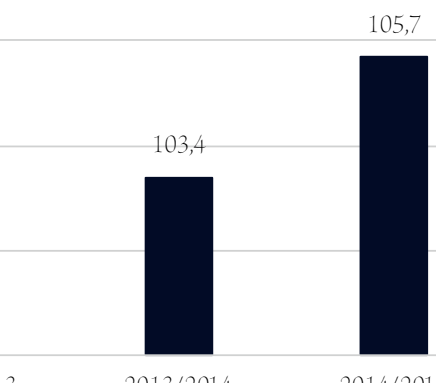

5,7

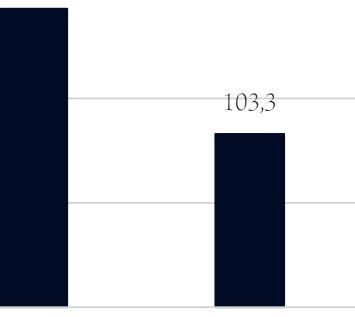

$2013 / 2014$

2014/2015

2015/2016

Źródło: Opracowanie własne na podstawie Orange Polska (2012a-2017a).

Privatization process of the telecommunications industry in Poland and the financial position of the Orange Group

\begin{abstract}
Motivation: Telekomunikacja Polska SA (hereafter TP SA) for many years had a monopoly position in the telecommunications industry in Poland. The company's privatization process began in 1998 , accompanied by changes in the telecommunications industry, towards its greater liberalization. The start-up of new operators has increased the level of competition. Services were becoming cheaper for consumers, companies started offering bundled services, and new telecommunications technologies were developing very quickly. The transformations that took place in the telecommunication industry had a significant impact on the changes in the financial position of the Orange Polska Capital Group (hereinafter the Orange Group). In the subject literature, there is a lack of interpretation of the relationship between the privatization process taking place on the telecommunications industry and the financial position of its former monopolist. The desire to show this relationship is the main motive for selection of the subject of this article.

Aim: The aim of this article is to demonstrate the relationship between the privatization of TP SA and the financial situation of the Orange Group. The research was conducted using financial and technical-economic analysis. The empirical material is the reports of the Orange Group.

Results: The analysis of the Orange Group's financial results in the audited period showed that the privatization of TP SA had a negative impact on the financial position of the Orange Group.

Keywords: privatization of TP SA; liberalization of the telecommunications industry; Orange Polska Capital Group; financial analysis; technical-economic analysis

JEL: DOO; GO0; B52
\end{abstract}

